University of Rhode Island

DigitalCommons@URI

Open Access Master's Theses

1960

\title{
A Unit History of the Second Rhode Island Cavalry
}

Donald Fisher Harrison

University of Rhode Island

Follow this and additional works at: https://digitalcommons.uri.edu/theses

\section{Recommended Citation}

Harrison, Donald Fisher, "A Unit History of the Second Rhode Island Cavalry" (1960). Open Access

Master's Theses. Paper 1816.

https://digitalcommons.uri.edu/theses/1816

This Thesis is brought to you for free and open access by DigitalCommons@URI. It has been accepted for inclusion in Open Access Master's Theses by an authorized administrator of DigitalCommons@URI. For more information, please contact digitalcommons-group@uri.edu. 


\section{A UNIT HISTORY}

$$
\text { OF THE }
$$

SECOND RHODE ISLAND CAVALRY

$$
1862-1863
$$

BY

DONALD PISHER BARRISON

A THESIS SUBMITTED IN PARTIAL FULFILLMEUT OF THE REQUIREUH WASTER OF ARTS

IN

HISTORY 


\section{ABSTRACT}

The Second Rhode Island Cavalry was activated by a state executive order over Governor Smith's signature on Auguat 31, 1862. It called for the formation of one battalion under the command of Major Augustus W. Corlisa at Providence, Rhode Island. Volunteering wont so well that on November 15, 1862, an addtional order was publiahod forming a full sized rogiment. After flling the ranks with men who were procured for the moat part by high bountles, the regiment loft as soon as possible for action in the Department of the Gulf at Hew Orleans, under the comand of Major Goneral Nathaniel P. Banks.

Having arrived in Now Orleans, the regiment was asalgnod varlous reconnalssance and patrol dutles within one of the divislons in Banks' command. An active part was taken by the regiment in the first move on Port Hudson In Maroh, 1863. A critical need for oavalry in the Department of the Gulf was felt by Banks and changed his omployment somewhat of the Rhode Islanders. Moving to the west of the Mississippl, parts of the Second Rhode Island Caralry were comitted in a movement all the way north to Alexandria, Loulsiana, In an effort to outflank the Confederate position at Port Hudson. When this falled, the unit was moved baok to the scene of the orlginal siege t 
Port Fudson.

Major Robert C. Anthony, executive officer of the rogIment, became 111 and was sent to Brashear C1ty, Loulalana for roat. In the path of a Confederate arive on New Orleans, Brashear Otty was readied for dofense, and plaoed under Anthony's command. The convalesoents were overcome by a taotical surprise and the ontire garsison was captured. Meanwh1le, the greater part of the regiment was on duty in the vicinity of Port Hudson. A skimish with two refiments of Arkansas infantry Inflicted several casuatios on the Rhode Islanders. In July, 2863 the regiment was went to Springfleld Landing to break up an attack by Confoderate raiders and again received casualties.

Reduced by battle oasualt1es, slokness, and desertions, the rogiment was first consolidatod into ono battalion by General Banks, then later deactivated. The offloers were released from the service, and the enlisted men were transforred to anotice cavalry regiment. In deflanoe of this deactivation, the onlisted men mutinied against colonel Haral Robinson, commanding offloer of the unit into whioh they were ordered, and the offloer charged with the responsibility of the changeover.

Robinson reacted violently himself to the muting, bringing up his own unit abreast of the Fhode Islanders, and threatening to 1 re if they did not move. As the mutiny subsided, he arrested the two ringleadera, and had them executed as an example for both units to soe. Foeling 
1n Providence was vary trongly agalnst goblnson for his action; however, nothing of consequence oame of it,

A Court of Inquiry was called by Banks which acquitted Robinson of all blame. The writer foels that Roblason, although acting in good falth and in the performance of hls duty, carried out the suppression with ruthless diaregard of the fact that the mutiny was at that time past the crisis, and that such severe mesure was not warranted. 


\section{PREFACE}

Tracing ant history is faselnating work, particularly if it is in the perlod of the Amerioan C1vil War. There is at present a reviral of interest in that war, in which the writer has been oaught up. Thle work soek to trace the entire ilfe eyole of a cavalry roglment from activation In Providenos, Rhode IsIand, in Apr11, 1862 to deativation in ThIbodaux, Loulsiana, in August, 1863. Partioular omphasis $1 \mathrm{~s}$ placed on the events that surrounded a miny in protest of the deactivation.

Souroes Inolude reports by state officis of Rhode Island, milltary reports from the offlelal reoords of the army in the war, accounts frow Providence newapapers, and secondary works. The for portion of the material used was found in the library of the University of Rhode Island and the Providenee Public Library. Som assistance was recelved through correspondence with private institutions and persons.

It is a pleasure to acknowledge indebtedness to a fow of the many individuals who advised and assisted mo in the completion of this work. While I express deepest approciation for their assistance, they are in no way responalble for the handing of the material or for errors in 
reot or presentation. I would especially like to thank Dr. WIIIIam Hetz for his advise throughout the work on this paper. The gonorous and skillful assistance of Dr. Daniel H. Thomas and Dr. Walter L. Simons was vory valuable in ashleving better organization and elarity. I cannot forget the enoouragoment and counsel of Dr. $1111 \mathrm{am}$ A. Itter over the pest throe jears, without which I could not have prepared myself for this fleld of study. I am 1ndebted to M. Francls P. Allen and the ataf of the Ilbraxy of the Untrersity of Rhode Island for their kind Indulgence, and to Mr. Stuart C. Shorman, LIbrarian of the Providenoe Public Library, and his ataff, partioularly Mrs. Eleanor Q. Fyne of the Referenoe Department.

some valuable assistance was obtalned from Captain Robert R. Rudy of the Office of the Chief of Military History of the Department of the Army, Irom Professor A. Arthur Sobllier of the Sohool of Law of Columbia Univorsity, and from Ur. W. Joseph Harrison, III, an attornoy In Philadelpila, Penneylvania, In rogards to the Camp Hubbard mutiny. Colonel Charles R. Herrmann and Major Blias B. Brand and other members of the Military Sclenoe Department of the Unlversity of Rhode Island were helpful wth thoir Interest and rather free uae of offloe hours. Without the long hours of patient and kind understanding of my wife, Catherine, this work could never have progressed. Her additionel editorial assistance before 
submitting the peper to my professors bolpod in the orerall preparation. The final typescript was made by her under varlous pressures of children, relatives, and an Impending military trangfer. Her influenoe was indelibly felt throughout all stages. 
ABSTRACT, ........................111 PREFACE .......................... . . . IIST OF ILLUSTRATIONS ...................x1 Chapter

I. PREPARATION FOR BATTLE. . . . ......... I Proooding Cavalry Regiment: Aotivation and Reorulting outfitting and Morement to Hew Orleans

II. OPERATIONS: MAROH TO JUDE, 1863.........16

The Firet Hovement on Fort Fudson

The Heed for Cavalry

Operations in Heatern Loulaiana The S1ege of Port Fudson

III. OPERATIOKS: JUHE TO AUGUST, 1863.........29

Brashear c1ty

The Forage Train Ineident

Spring fle Id Lending

Port Huds on Falls

IV. MUTINY AT CARP HUBBARD. ............42

The Reduction

The lutiny

Robinson's Actions

The Execution

v. DISCIPLITE AND MORALE. ............50

Problems at the Befinning of the far

Huting in the Cavalry

Adniniatrat1ve Disolpline

Pro Problem of High Bountie

"Bounty Jumpers"

Deaertion Fotals

Axing Justico 


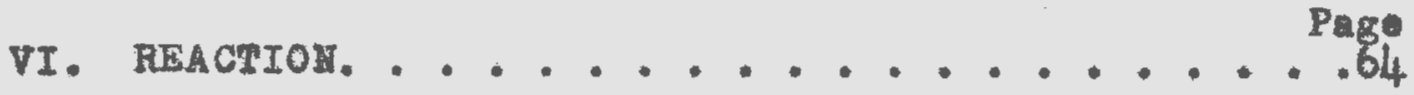

The Court of Inquiry

Reaction In Rhode I land

The Third Rhode IB land Cavalry

VII. OBSERVATIONS. . . . . . . . . . . .71

Was there Muting?

Colonel Robinson's Actions

Conclusions regarding the Mutiny

Effectiveness of the Second Rhode Island Cavalry

APPENDIX A. : . . . . . . . . : . . . . ....80

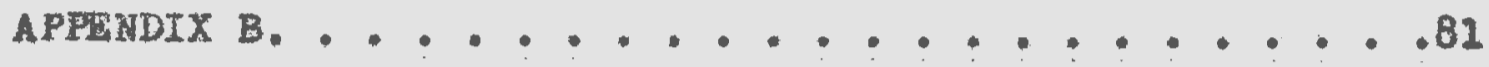

BIBLIOGRAPHY. . . . . . . . . . . . . . 84

$-x-$ 


\section{LIST OF ILLUSTRATIOIS}

Plgure

1. State of Rhode Ialand General ordors

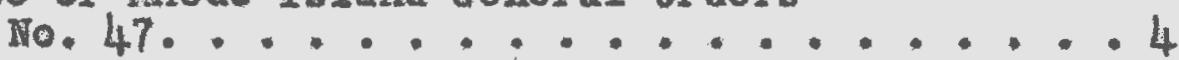

2. Advertigement in the Providence Dally Post, Ootober 4, Tr6z, ....... 6

3. Advertisement in the Providence Dally

Post, November 11, $1862 \ldots . . . . .6$

4. Map of Port Hudson and Vieinlty .........23

5. Theater of Operations for the Department of the Gulf, Maroh to August,

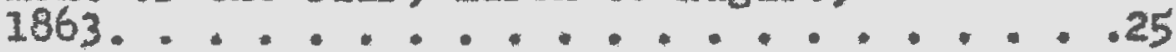

6. Route of General Taylor's Rald, Mane 10 to June 23, 1863,................... 
CHAPTER I

PREPAFAIIUY FOR BATTLE

Proceding Cavalry Regiments

The Battle of Bull Run, fought in 1861, polnted out many thing to the inexperienced, lmpatient people in high places of the Federal government. Probably as important as any other lesson learned from the battle was that there was shown the neod for reconnatssence and security troops. Units noblle onough to traverse great distances, relatively unobserved by the onemy, and yet with suffloient roroe at their disposal to create a striking force to proteot themselves wore needed. The angwer could only bo found in the mounted soldier, the cavalryman. General ifoclellen foresaw this need early in the war and pressed the war Department for cavalry units undor his comand.

Fhode Island contributed its full share of oavalry units. There was first activated Hew England Caralry Regiment that contalned some thode Island volunteers. Water, the How Hampshire Cavalry was activated, containing a Phode Island Battalion, mostly of men from the Providence area. The state was finally glvon full-gized unft of its own when it gainea permission to form a volunteor unit, the First Rhode Island Cavalry Reglment. 
Sent away with much pomp and ceremony, tino First Rhode Island Cavalry asalgned to the Army of the Potowac in March, 1862. Highly rogarded by many, it nobly upheld the name of the state, giving Rhode Island 1ts plrst military heroes of the war. Books axtolling its record were written, persons were decorated, and the unit was hoaped with gifts by the eltizens of the ata. The Mrst Thode Island Cavalry Regiment continued in existenoe throughout the war, partiolpeting in all the mejor actions of the Army of the Potomac in the Eastern Thoater.

Spurred on by the sucoss of the First Cavalry, Rhode Island activated the Serenth Squadron, Rhode Island Cavalry, In June, 1862. This unit consisted of the equivalent of only one battalion of three month volunteers and was sent to Wasington during the soare osused by Confederete General "Stonewall" Jaekson's operations in the Sinenandoah Valley.

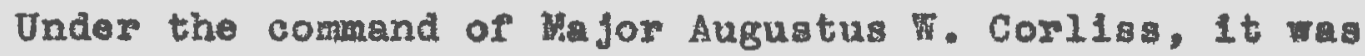
assigned to Brigadier General Jullus White at Harper's Ferry on September 5, 1862.1 September 8 under Major Corliss it was sent on rooonnalssance into Solomon's Gap. It traveled south to Jefferson, Virginia, and drove in enemy plokets. Capturing twenty-five prisoners, it pushed on to within two

1U.S.War Department, War of the Fobellion: A Compllation of the offielal fecords of the Union and the Confederate Armies (128 v01s.; Washington: Government Printing of $100,1880-1901)$, Series I, Volume XIX, Part I, Reports, p. 533 . Hereafter referred to as OR, followed by the serles, volume and part, if any, all in Arablo numbers. (Above referense would be OR $1-19-1, p .533$. 
miles of Jaskson's main srmy, and returned without loss.1

\section{Actiration and Recrulting}

Meanmile, manpower shortages in the Federal Army were being felt by the nation, and on July 2, 1862, President IIncoln issued all for 300,000 more volunteers. Rhode Island'g quot was partially satisfled by tho activation of two new volunteor units, the Seventh Rhode Island Infantry, and the second Fhode Island Cavalry. These two eventually accounted for about half of the quota.2 The oall was for a three year term of onlistment and by September the War Dopartment had sent its apecifles to the Governor of Ahode Island. The Adjutant General of Fhode Island, on Ootober 2, 1862 , ordered the actiration ${ }^{3}$ of one battalion of caralry under the comand of Major Corliss. The Seventh Squedron was now on Its way homo, and Mafor Corllss was called to Wagnington to appear as a witness at an Army Board of Inquiry. After appearing on Ootober 21,4 he journeyed back to Providence, where he took an active part in recrulting volunteors for the Second Regiment.

Alroady in Providence to take charge of the recruiting program was Captain Robert C. Anthony. Captain Anthony, a

IOR 1-19-1, p. 535 .

${ }^{2}$ Ibid., 3-3, p. 780. The serenth (939), and the second $(714)$, totaled 1,653 volunter soldiers and officers.

3 see Figure 1, page 4.

$40 \mathrm{R}$ 1-12, p. 791 . 
Fisure one

Genoral orders, No, 47. Adjutant General's orfleo, Providence, 0otober 1, $2,862$.

In pursuance of authortty recelved from the seoretary of War, the First Battalion, second Roglment Rhodo Island Cavalry, to be under the comand of Major Augustus $\mathrm{W}$. Corlise, to serve for a perlod of three years, or durling the war is beraby ordered:

The camp is atabliahed at the "Dextex Pralning around." Tho Battalion $w 111$ be ortanized as follows:

One Major

One Battelion Adjutant

One Battalion Quaistermatis:

One Aralatent Surgeon

one Battalion Bergeant Major

one Bettalion Cuartermaster Sergeant

one Battalion Comal ssery Sergeant

One Battalion Hospital stevard

One Battallon saddlez's Sorgent

One Battalion Veterinery Sergeant

Four Captains

Four First Lieutenent:

Four second Hleutenunts

Four Mirat Sergeants

Four Company Quartermaster sergeant:

Pour Company Commissary sergeants

Twenty sorgente

Thlrty-twe corporals

Elght reamsters

Elght Farriers or Blackant ths

Four seddlere

Four Vagoners

Three hundred and twenty Frivates

By order of the Comander in Chief:

EDARD C. Haran, A.6.

1g. 1.-Stato of Rhode Islend General Orders No. 47. It appeared in the Providenee Daily Post, detober 3, 1862 , p.2, 0.7 , and ran for five days. 
native of west Providence, had origlnaliy been comissioned In the First Rhode Island Cavalry, and in that unft had commanded the third battalion. On Apr11 16, 1862, he sew action at Warrenton Junotion, Virginia, with his unit. Lator In General Aberoromble's brigade, he took his bettalion duep behind Confederate Ilnes on a reoonnalsance to the Rappahanock River. By Ootober, 1862, he was baok in Providence holping to form the Second Cavalry.1 Captain Anthony set up recrulting offlces at the corner of Orange and Westminster street and started to seok for hls company. 2 Taking an advertisement in the grovidenoe Dally Past on october 4,3 he continued 1 t to Docamber 22. By Hoveraber, men were tarting to come in, and lajor corliss was able to set up the framework for aocoting reoruita into four companies. Company A was reomitid by Captain Anthony. For oommand of Company B, anoticer former Seventh squadron offlicer was selected, Captaln George A. Smith. A former enllsted man, he had been commlssioned in July, 4 and sont home to recruit for the new reginent. He was comissioned a captain on october 3 ,

I Apparently he was called back, but by coming, he had to cocept a one grade reduction, for he had hold a major's comission in the firgt Cavalry.

2phroughout thls work, the eavalry "troop" is referred to as a "company." According to the common usage of the perlod both torms are correct and refer to the same size units. The same reasoning would refer to the "squadron" and the "battalion," "hich 1 s the next larger unit. 3P.2, c.4. See Figuro 2, page 6. 4Prov1denoe Journal, september $2,1862,0.2,0.4$. 
Flgures Two and Three

ATTENTIOA TROOPERS!

OFF FOR THE WAR AGAIN!!

Young and Active men wanted for a Troop: of Horse for

the second Rhode Island Reglment Cavalry.

This is dashlng and pleasant servioe, and young men oan all make good hor beran.

office, Corner of Orange and westminster streets, upstalrs, room, 5.

F. C. Anthony

Gaptain, Second Rhode Island Reglnent, Gavalry

Fig. 2.-Advert1sement in the Providence Dally Poat, october 4, 1862, p.3, 0.1, appoarinf From that date unti December 22 .

\section{HURRAH POP TEXAS!}

\section{THE LAND OF" MILF AIND HONEY! :}

The Flrst Battalion second Reglment Rhode Island Cavalry, under the commend of Major A. W. Corliss, nas been ordered to join the expedition of General N. P. Banks, destined for rexas. No is the timo to join this crack regiment. By so doing you will escape the mud and snow of Virginia, and the cold winter of the North. Bounty $\$ 25$ wen sworn into service; $\$ 300$ when you leave the state and 75 when discharged,--A good opportunity to settle on the rien oralries of this noble state, is of pered at the olose of the rebellion. RECRUITIJG OKTICXFS: Captain K. C. Anthony, corner Orange and westminster Streots, upstalrs; Captoin G. A. Smith, Dorrance Street; Captain Willam ${ }^{2}$. Stevens, corner Horth Wain streot and warket Square. The Fourth Company is recrulting at Camp auran.

A. Worl1ss

Ma jor, Commanding

Fis. 3.-Advertisement in the Providence Dally Post, Hovember $11,1862,0.3,0.3$, running until January $23,1863$. 


$$
-7 \text { - }
$$

1862, I and took up recrulting offlces on Dorrance street in Providence. Commanding Company $C$ was Captain William H. Stevens. Also a veteran of the seventh squadron, his original commision dated from the preceding. June, when he had served under Anthony.2 He left to help in the ner unlt and Tas comisaloned captain by the governor in Oetober. He set up recrulting offices on the corner of North Main Street and farket Square. Company D was recrulting at Camp Mauran and was without a commander until Decenber, when Gaptain George W. Beach appointed rrom Boston, Masachusetts. 3 On November 11 Major Corliss put an advertisement in the Providence Dally Post, asking for men for the battalion and announoling that the regiment was to bo committed in an expedition under General Banks. 4

foorulting progressed very rapldiy, and by November 15 the governor athorized the activation and reoruiting for a seoond and third battalion. 5 uajor Corlis was promoted to

Istate of Fhode Island, "Adjutant General's Report for the Year 1865," Realster of Fhode Island Volunteers 1861-65 (Providence: Provideneo Press Company, 1877), p. 209. Hereafter referred to as Reglater.

2 Frovidence Journal, september 2, $1862,0.2,0.4$. 3reg1eter, p. 166. 4..3, 0.3. See Plgure 3, page 6. 5 The third battalion though authorlzed was never realized. 
Iloutenant Golonel. 1 A General Order of the Adjutant General of Rhode Island was published similar to that shown in Figure 1. To help out in the formation of the second battalion, Captain Charles N. Manchester of the First Rhode Island Cavalry was brought home and oommissioned major. Manchester hed been a lieutenant at the Varrenton Junction action with Anthony, and the two were reported to be good friends. Major Manohester took up quarters at Fo. 18 Dorrance street and supervised the recrulting for the second Battalion, which consisted of Compenies E, F, G, and H. 2 Commanding Comony E was Captain Edwin A. Hardy, who ot the time of the orlginal activation had beon appointed adjutant. By January 15, 1863 , he was promoted to captain. ${ }^{3}$ Commalng Company $\mathrm{F}$ was captain Poter Bruoker. Commissioned in January, 1863.4 Bruoker wes a very popular offlcer and was frequently invited out to the homes of the better families of Providence during his perlod of recrulting. According to the Providenoe Dally Post, he galned the affoction and esteom of his men quickly, and was able to establish a high degree of disolpline.5

IState of Rhode Island, Annuel Report of the Adjutant General of the State of Rhode Island and Provldence Plantations for the Yoar 1865 , by Brigadiar General EIIsha Dyer (2 vols.: Providence: E. L. Preeman and Son, 1895), II, 159. Hereafter referred to by the author: Dyer.

2Prokidence Dally Post, January 30, 1863, p.3, c.1.

3Ib1d., January 17, 1863, p.3, 0.1.

4Register, p. 169.

5 Jenuary $26,1863,0.2,0.5$. 
A former enlisted man frow East Greenwiob, Rhode Island, was selected to command Company G, Captain William W. B. Greene was a private in Company E won his appointment as captain was made by the governor in January, 1863.1 Company $B$ was muatered in later than the rest, and Captain George Fenry Getche11 was not combissioned as a captain by the governor unt11 March 14,2

\title{
Outfltting and Hovement to New Orleans
}

The mision that was to be the regiment's was estabIlshed as "Southern Expeditlon" when the Governor rocelved the following message from Secretary of War Stanton:

General Banks has establlshed hls headquarters in Nev Tork to organlze southern oxpedition. All the troops in your state not otherrise appropriated are placed at his command, You will please confer th him, anawer his requidtion, and render him every ald in your power to speedily orgentze his conzmand. 3

By this arrangement a tomporary hoadquartors was set up in New York, and mach of the direotion of the Department of the Gulf was conduoted from there. Colonel corliss left in December for New York, where he ohocked in and then left by ocean steamer for New Orleans. As each compeny left Providenoe, it likewise wont to New York, and then to Now Orleans by ocean steamer.4 Hajor Manchester was lert in oharge of the

\author{
legesiater, p. 182 . \\ 2Ibld., p. 181 . \\ 3october 28, 1862, OR 3-2, p. 691. \\ 40bviously, the military ituation at that time would \\ not allow Iand travel betweon Rhode IsIand and Loulsiene. \\ Therefore the safest and most conomical means was by ocean
}


rogiment's affairs in Providence.

Meanwhile, the two battallons had to be outfitted by the state of Rhode Island before they wore mastered into Federal service. This was the respondbility of the state Quartermaster General, and Involved many things. The men had to be given uniforms. They had to be given weapons. During their perlod of activation they had to be fod and tralned. Horses had to be bought, red, and eared for. Barracks had to be prooured. In addition, it was the responstbility of the state of Rhode Island to transport these men to New York, where they were muatered into Pederal servioe.

Durfing the yoar 1862, the Rhode Ialand State Finaneo Comitteo reported total expenditure by the state Quartermester General of $8,527.74$ for the second Fhode Island cavalry. 2 This figure did not include elthor the bounties pald to the men for volunteering or b111 for $\$ 11,000,00$ for the purchase of the horses.3 For the year 1863 the

steaner Prom Hew York to Her Orleans, which by that time had bean reocouplod by an amplblous asault, and was under military occupation by Major General Benjamin Futler.

IProvidenoe Dally Post, January 30, 1863, p.3, c.1.

2state of Rhode Island, Report of the Finance comittee upon the Acoounts of the Adjutant General, Quartermaster General and Genoral Treesurer Fobruary 10, 1863 TFubllo Document No. 14 to tho hatg and Resolves of the January session for 1863 of the Rhode Island State Legislature; Providenee: Alfred Anthony, 2863), p, 12 .

3roport of the Finance comaltter, p. 3 . 
total was $\$ 8,792,10.1$ Insluded wero a sundry of varied expenses. For instance, $\$ 30.00$ was spent to clean an armory in Providence which was used for a barrack; $\$ 62.70$ Was paid to tho Providence Gas Company for gas used at the barracks; and $102.00 \mathrm{was}$ paid to Lewis $P$. Child for rent and damages to the rooms at the barracks. 2 That totala almost $\$ 200.00$ for the barracks alone. The $\$ 11,000.00$ previousif mentioned for the purchase of horses represents only portion of the cost for them. The interest to the bank on the loar to buy the horses totaled $\$ 1022.54$, about 10\%. On December 29, 1862, W1111am E. Iaml1n was pald $\$ 24.25$ for hora medicino. Tromas A. Howland was paid \$328.25 for branding the horses and shipping them off to New York. Later for forage furnished to the horses in New York, Mr. Howland received $4.772 .431^{3}$ Thls ropresents a total of $17,147.47$ for horses.

There is a reasonable doubt that there was much training In Rhode Island for the regiment. The unfts spent most of their time gotting the men established into companles and organizing all the varlous sub units. Hon-commisioned offlcers had to be appolnted. Other company officers had

Istate of Rhode Island, Report of the Quartermester ceneral, George Lewls Cooke, Made to the General Aasembly of the State of Rhode Island at its January Session, 1864 (Pubilc Document No. 3 to the Aots and Resolves" of the January Session for 1864 of the Rhode Island state Leglslature; Providence: Alfred Anthong, 1864), pp. 27-28.

2 Ibld.

3 Ib1d. 
to get accustomed to the companies.

The First Battalion departed in December. Companles $A$ and $B$ left for Hew Fork on Docomber 2, 1862. Company $C$ left on December 12, and Company $D$ on Deosmber 29.1 The battalion had flled replaly and most of tho avallablo manpower had been used up. By the time the second Battalion was flling, there were many outsiders, slackers, and ruffians who appeared before the recruters, not because of patriotle zeal, but for the bounties offered. Many never reached the battlefield, but deserted. 2

This second Battalion, then, spending the most tine fliling in Providenoe, presented the mot news to the publio. on Jamuary 26, for 1nstance, Goupary presented Providence with a street parade, socospenled bj a brass band. "They appoared finely, being all ten of good phjslcal development and moving with precision." 3 The men were restioss, as soldiers at ldle pertods are, and they hed their share of atreet brawls. The sling shot was favorito weapon and in one Instance, a "Dutchman and two Irishmen" got Into a brawl in which one man recolved "two or three serere blows on

Istate of Fhode Island, Annual fieport of the Adlutant General of the state of Phode Is land for the Year 1862. presented to the Honorable General Aarebly of the state of Phode Island in Providence, December 31, 1862 (Providenee: Alfred Anthony, 1863 ), p. 7 . chapter.

2xoralo and digolpline will be dealt with in a later

3 Providence Dally Post, p. 2, 0.5 . 
the head." I In another brawl on Broad street, four men pursued another into on otor saloon and dellvered sabre wounds as well as those from a sling shot.2 on the afternoon of the twenty-ninth, fifteen or twenty reorults from Company 6 left their barracks and travelod about the streeta singing, shouting, and insulting people whom they net." 3

These "muffians" of the Seoond Battalion ereated much confusion and bitterness from the start. An excellent -xample is Company E, the "German Company." This company recelved its name from the fact that the recrulting officer and most of the men rocruited by him were German lmmigrants. Acoording to a nowapaper account, an agreement existed between the recruiter and the recrulted that they should secure the state bounty and then desert. When the facts became known, the provost larshall took swlft aotion. All wore placed in detention and taken to Fort Adans, near Newport, Rhode Island. There the were put under the survelliance of one hundred and fifty rogulars.4 Later the whole unt was plaoed on board the schooner, Loulga H. Endicott, and Provost Marshalls from other states were brought on board to identify deserters and from other rocrultments.5 Meanwile,

IIbld., January 23, p.3, 0.2.

2Ib1d., January $28, p .3,0.1$.

3Ib1d., January 29, B.3, 0.1.

4Regular Army troops.

SProvidenoe Da11y Post, January 14, p.3, c.1. 
Captain Hardy was glven command of the unt, and they were brought back to Providenoe. They wero allowed to come ashore only briefly to be sworn into Federal service, and then made to go back on board the sohooner. By this time, there were only ninety-two left of the orlginal one hundred and five. The rest had deserted. The sohooner salled for New York, from whence the men were to go to New Orleans. Lutz, the 11logal recrulter, was taken to fort Lafayetto, New York, where he was to andwar other charges more grave than the ones in Fhode Igland. 1

Company 0 had its ahare of these men also. The tate bounty was not pald unt1l the company reached Hew York. Bren then 1t wasn't pald unt1l the men vere on board the transport that was to take them to Now Orleans. After the bounty was pald, six of the men jumped shlp and hid on board a stom-tug that was alongside, dscharging grain for the horser. They were detected and taken buck, and placed under guard. F1nelly, the guard, together with the six original men, and eleven others all suocoeded in making good their oseape.2 Five other deserters were apprehended from a group that had eacaped from Long Island aftor havlng boon pald the three hundred and twenty-plve dollar bounty. Two had gotten to Portsmouth, New Hampshire, and three to

I Ibld., January 19, p.3, 0.1:

IIbld., Fobruary 7, p.3, c.1. 
Boston, Nassechusetts 1

Each company of the Second Battalion lert as soon as

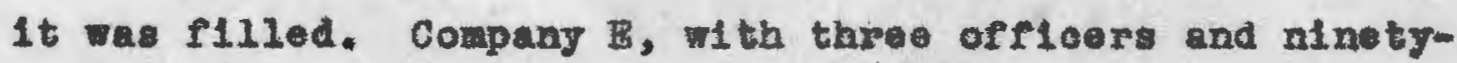
nine men, left on January 23, Coapantes and 0 , consisting of three offleers and one hundred men each, left on Jamary 31) Company H, Wth two offlcers and $1 x \mathrm{ty}$ men, departed on March 28.2 Trapportation was by train to Ma York by way of Groton. At Now York, they were transforred directly to a trandport.3

The transports Crescent, Belle wood, and Indeunted, 4 steaned out of New York harbor and took the long royage down the Atlantio sobbord, around Mor1da, Into the Gulf of Mexieo, and then up the Hissiseippl River to Nev Orlean.

IPeovl denoe Delly Post, Jamuary $23,0.3,0.1$.

2state of Thode Island, Annuel Report of the Adfutant General of the state of Phode IsIand and Providence Plantationa ror the Year 1863 (PRbII0 Document Appendix Mo. 4 to the "Acts and Regolveg" for the Jamuary seaten of the Rhode Island state Logislature for 1864: Provianos: Alfred Anthoin, 1864), P. 2.

3 Providenee Dally Post, January 28, p. 3, e.1. 407 2-15, 673 . 


\section{CHAPTHE II}

\section{OPRRATIOLS: NAROA TO JULE 1863}

\section{The Plrot Movement on Port Hudeon}

With the exception of company H, the entire regiment olosed into the Departmont of the culf theater of Operations by Uareh 5 . Companios $B, C, D$, and $F$ arrived on Pobruary 13 from Hew York. 1 Ther debarked from troop steamera at How Orleans: horaes, men, veapons, and extra equipmont, all hed to some off. The men were tired from the long ocean royage. The last to unload was company $G$, and colonel corllss consolidated the regiment for movement into the combat zono. Thes embarked on ocmmandeered river boats, and started up the MIsiselppi Hiver to Baton Rouge. ${ }^{2}$ Compang a was loft beck in New orleans to guard the baggage and aupplieg. 3

The genoral moremont against Port Huduon was one or grest atrateglo and national importanee. The year before.

\section{$10 \mathrm{R} 1-15, \mathrm{p}, 673$.}

2Prederick E. Dyer, A Compendium of the War of the Rebellion ( 3 vols.: Volume I, Rumber and Organization of the Armies of the United States; Volume II, Chronolosical Record; VOIume III, Roglmental Histories; Nor York! Thomas Yosolor? 1959). III, I627. Bereafter reierred to as Dyer, Compendium, with the volume and page in arabio mubers.

3ulltary baggege and auplles, whith could inolude rations for the troops, forege for the horses, cumuntion, extra weepons, heevy equipment for englnoering work, to. Thi was normal tak for a troop (or company) of oavalry. 
whon Adalral Farragut steamed up the mouth of the Misalsalppi, and General Butler' troops stormed the olty of New Orleans, Prosident Lineoln saw possibilities of boing able to put the Anaconda Planl Into offoot. General Grant's forces had been moving down the misalssippl River for soveral months. The Shlloh Campalgn, Irland No. 10, and the move on Vloksburg. wore all destined eventually to out the Confederaoy in two. The tates of Loulalana, Pexas, and Arkansas mould be severed from the reat of the Confoderaog, and Texas beer would no longer travel along the Vloksburg Rallroad to supply Lee's Aruy of Northern Virginia. With genoral movement by Grant, now In comand to the north againat the bastion of V1cksburg, matched almultaneously by Genoral Banko' morement in the south agsinst Port Hudson, the Morth would be able to out off the last two strongholds on tho Misiselppl and make the oplit a roality. Both Banks and Grant know this. Bowever, ench general, thlnklng hls own campalgn to be the more 1mportant, felt, with good besis, that the other chould coonomize his forces to the bone, and release the rost to be used in one orerwholuting coneentration of force to defoat onoh Confoderate stronghold in dotall. Eaoh man was stubborn. Both campaigns as a result wore to drag on not only agalnat the oneng, but the tompers and patienes of these two generals. It was only when Grant was ablo to conoentrate against the rear of Vloksburg, that he was able to foroe a dooleion. After 
depleging rare show of pluck and daring, ho serored his 1ino of comateations and struck out on tiad. on July 4. 1863. Pomberton at V1okeburg asked Grant for torms. As soon as the Confoderate troopn in Pert Eudson learned of the Vlektburg anrender, thelf righting spixit wanod, and it was only a watter of time unt1l they would bo foreed to trike thelf loolers.

The story of the Second Rhode Iland Cavalyy 1s oodyered around this aloge by the Departaent of the oulf (In reallty an Army Corps, the Hinoteenth), againgt Port Hudson. The Rhode Ialand regiment was one of four auralry untts in support of four larentry diviatens in the corpe. Two of those cavalry units, the second Rhode Itelnd, and the Firet Loulatana, were in the same atvision, under lajor deneral Christopher o. Augur. Ceneral Augur's difision, comanded by anfor general, and having moro eavalyy than the others, was naturaliy the one in the thiok of the fighting. The Seoond thode Island Gevalry, a seasoned group, 1 recelfod tadks commensurate Ith 1 ts experienoe. The other wait, the Fist Leuisiane Caralry under Colonel (then Major) Haral Robinson, was a now one. Recrulted mostiy from the ocoupled terwitory of Now Orleans, horsed and men were not acoustomed to the rigora of flghting. Before many days had passed,

IAlnost all or the offloers bad been in tho seventh Squadron, Fhode Island Gavalry, seelng ma jor dotion at varrentos Junotion gafnet stonewall Jackson in the shenandoak Valloy. 
however, the Loulaiana Cavalry gained experience, as did the other unfts in the Departrent of the Gulf.

\section{The Need For Cavalry}

Goneral Banks was in great noed of cavalry throughout the entire campaign. In the months proeeding the general movement on Port fludson, Major Robinson scoured the area around Now orleans looking for sultable mounts for his own and the other units that were due to arrive. Robinson's report to General Banlss is Indicative of how urgently the Department needed the cavalry service. The shortage of good horses in the Now Orleans area was probably due to Confederate requirements of the previous year. However, there were several hundred available. Good horsemen existed in the infentry units already in walting to move on Port Hudson. There were some oavalry oarbines avallable; cut down shotguns could be used as a substitute for the rest. Saddle makers were in New Orleans, and could be requisitioned. The shortage of sabres was not important, since the Departw mental Quartermaster was equipped to manufacture lanoes. ${ }^{2}$ Within a month, Roblnson had to admit that ho had been unable to get more than two hundred horses. There were no spares in his own command of about flve hundred men, and, if new cavalry unfts were made using the oxlsting horses, spares

IOR 1-15, pp. 652-53. Th1s is not too unusual to oreate new units in a combat area. One can seo how desperate cenoral Barirs was. Presumably the lanees would have been made of mood. 
would not be avaliable for any of the units then in exigtenoe. The only answer to the problem, reasoned Roblnson, was to import horses from the North, and to insist on better care of those in use in tizo volunteor units. 1 Novertheloss, Cenexal Banks directed that some units be "extemporized" from the infantry, and waited for the arrival of the seoond Rhode Irland Cavalry.2 Later, Banks was to feel the noed of the cavalry that ho so desperately wanted before moring out of New Orleans agalnst Port fudson. To do the outpost ork and soreening misstons 3 that were expected of highly wobllo cavalry, largo detaohmonts of infantry were being wastod. These were slow and unoerteln and could not duplloate what small partien of caralry could accomplish spoedily and coourate1y." A brigade of Infantry, for Instance, could not cover the frontage that a squadron of cavalry could control.4 With the $108 \mathrm{~s}$ of a Hassaohusetts unit, the Second Rhode Island Cavalry pas indeed a bleselng

By March 7 the whole movement got underway. Admiral Farragut requisitioned onough river transportation to start some of the units forward. Those units that did not take the river, started north on the road. General Augur's infentry

IIbla., p. 1103. To transport horses on a sea journey at that time deranded great care, and the only method of traneportation and communioation with the Iorth was by the two wook sea voyage from How York by ocean teamer.

2Ibid., F. 619.

3Reconnalssance and outpost protection.

4OR $1-15, p .259$. 
division arrived t Baton Rouge on Maroh 13, and Imediately took up defensive positions. In 211 , General Banks had soventeen hundred troops at Baton Rouge. As soon as the Rhode Islanders arrived, General Banks pushed them out in front on the road to Port Hudson. Temporarliy assigned to Generel Imory's division, Companies B, C, D, and $E$ went out In front to recomnolter, I with orders to out down the flank bridges. Compan F stayed wth about three thousand other men under Colonel T. S. Chickering to guard the roar of the colume at Baton Rouge.2 Then General Banks attempted to make some type of contact with Admiral Farragut up the river from Port Hudson. He sent Colonel Parmele with six companies of the 174th Now York and Companies $D$ and $E$ of the seoond Rhode Island Cavalry. The returned nnsucoessful, because Port Hudson had been fortifled by the Confederates. 3

\section{Operations in Western Louislana}

Upon finding that Port Hudson was fortified, General Banks bandoned bi original idea of jolning Grant before Vicksbarg, and prooeded to deroto all his attention to the

\section{IOR 1-53, pp. 549-50.}

2Richard B. Irvin, History of the Hineteonth Army corps (Hew York: 0.P. Putnan's Sons, 1892), p. 77.

3rbla., p. 83. Irwin oltes a "squadron." Th1s could mean possibiy anthing with the exception of Company $F$. It 1. ssumed to be Companies $D$ and $E$ since they were used later for simliar mision on the 27th. 
objective before him. 1 Koving alrectly north, with the Misissippl River on his left, Banks selected two parallel roads leading to the fort. (See Figure 4, page 23). Finding that the position was hogvily fortified, ${ }^{2}$ he decided to use a sall force to keep the confederates occupied, and try to move around them. This neant going through western Loulsiane. He out across the river, and went through the nock on Grand Lake, then moved across the Atohafalay Bayou, and up the Bayou Teche.

By now the flood waters of the Loulalane spring were beginning to take their toll. The river was unualiy high, making the bsyous runing into it swollon. Before the confedorates had left the area, they had out all the levees and oonsequently a great deal of the area weat of the risisalssippl River as a swam. At one point, the troops took an entire day disembarking from their boats, an operation that nomelly might have taken half an hour. After finally. getting ashore, contact with the onemy was rosumed. Confederate General Rlchard Taylor, commanding the opposing force, sucoeded in evading Banks, foreing the frederal troops to pursue tho Confaderates all the way nortin to Alexandria.

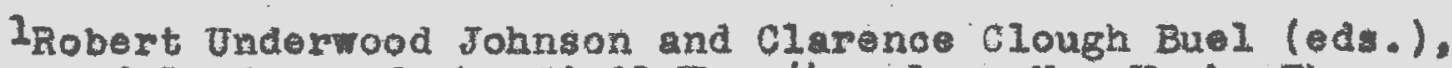
Battles and Leaders of the Clv11 War ( 4 vols.; Hew York: The Century Company, 1888), III, 586. The Capture of Port Hudson, by Rlohard B. Imin, U.S.V. (Hereafter roferred to as gateles and Leaders followed by the page, since there is only one seloction raod.

2 Approximately 20,000 men versus Banks' 14,000 . 


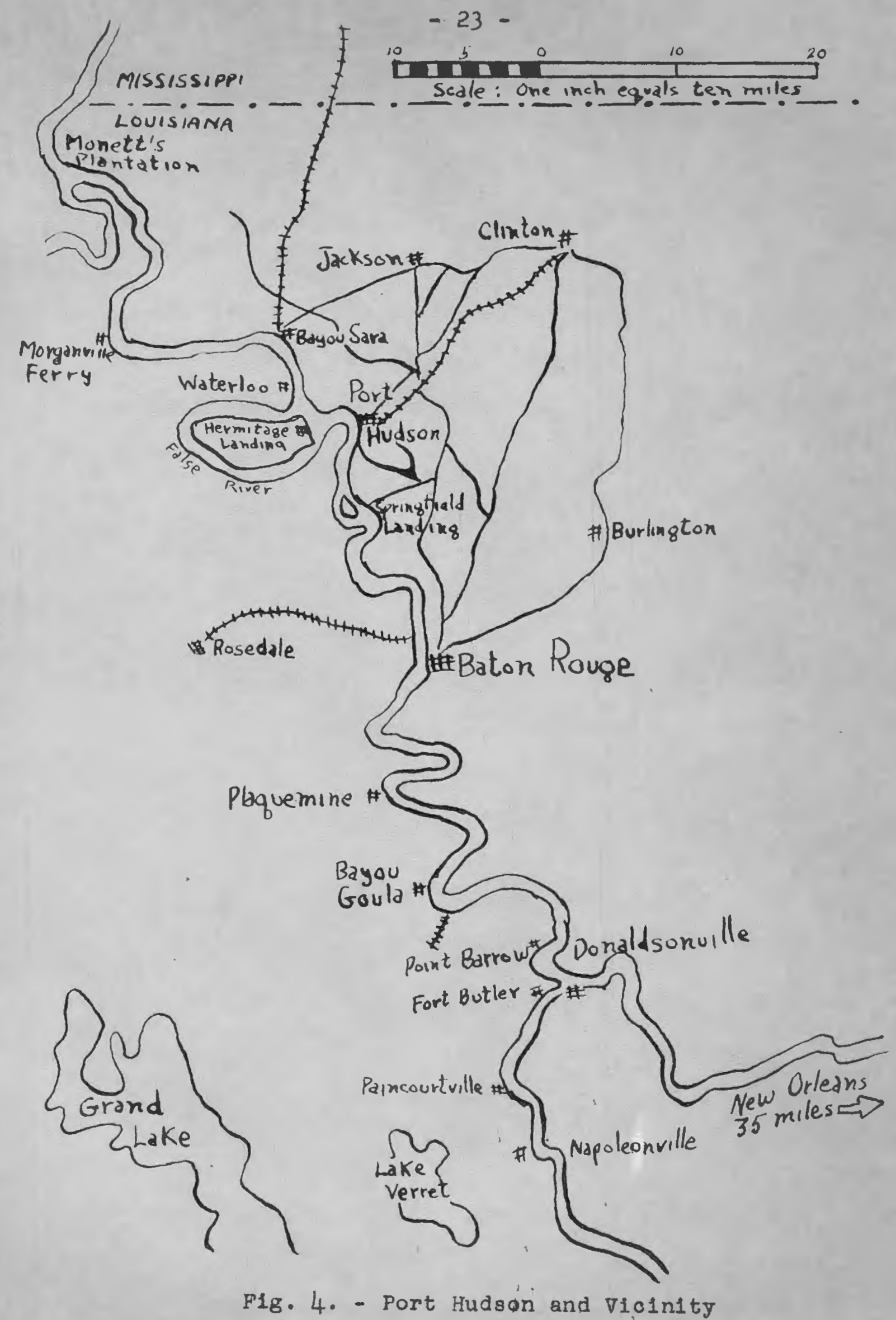


(See Plgure 5, Page 25).

During this movement, the Second Fhode Island Cevalry was split up into many forces, each company being loaned out to an Infantry commander as a reconnalssano foree for an expodition. Companies $D$ and $E$ wero given to Dudloy'a Brigade to help hiln gocomplieh his mission of opening up comanioations with the naval foroes to the north. They succeeded in moving around Port Hudson to polnt on the Mississippl noar the mouth of the False River called Hermitage Landing.1 (See F1gure 4, page 23). Company was atill with the fleld trains, and Company $A$ in Hew Orleana.2 Heanwile, Colonel Corliss noved along with the maln party of Banks' foroe, from Alglers, to Bemwlok, and, by Apr11 14 , to Frankiln. 3 The two companies that wore detalled with General Emory's division acoompanied the Fourth Hisconsin and one cootion of artillery for a special reconnoltering party all the way to Bayous Cooodrto and Booufr, found the bridges destroyed, and lost sight of the eneray. 4 on Apr1l 29 corliss was

IoR 1-15, p. 257. Thls foroe also Inoluded Compeny B, Massachusetts Unattaohed Cavalry.

2This 18 not olear, since, during this perlod, General Dyer's acoount 118 ts one of the companies as a bodyguard for General Banks." It is assumed that this would have been Coxpasy $A$, or the only other on unacoounted for, Company B. At this point Company $B$ had not oven arrived at Now Orleans, having left Providence on Harch 28.

3Dyer, Compendium, III, 1627.

4Apr11 21, OR 1-15, 29. 29, 


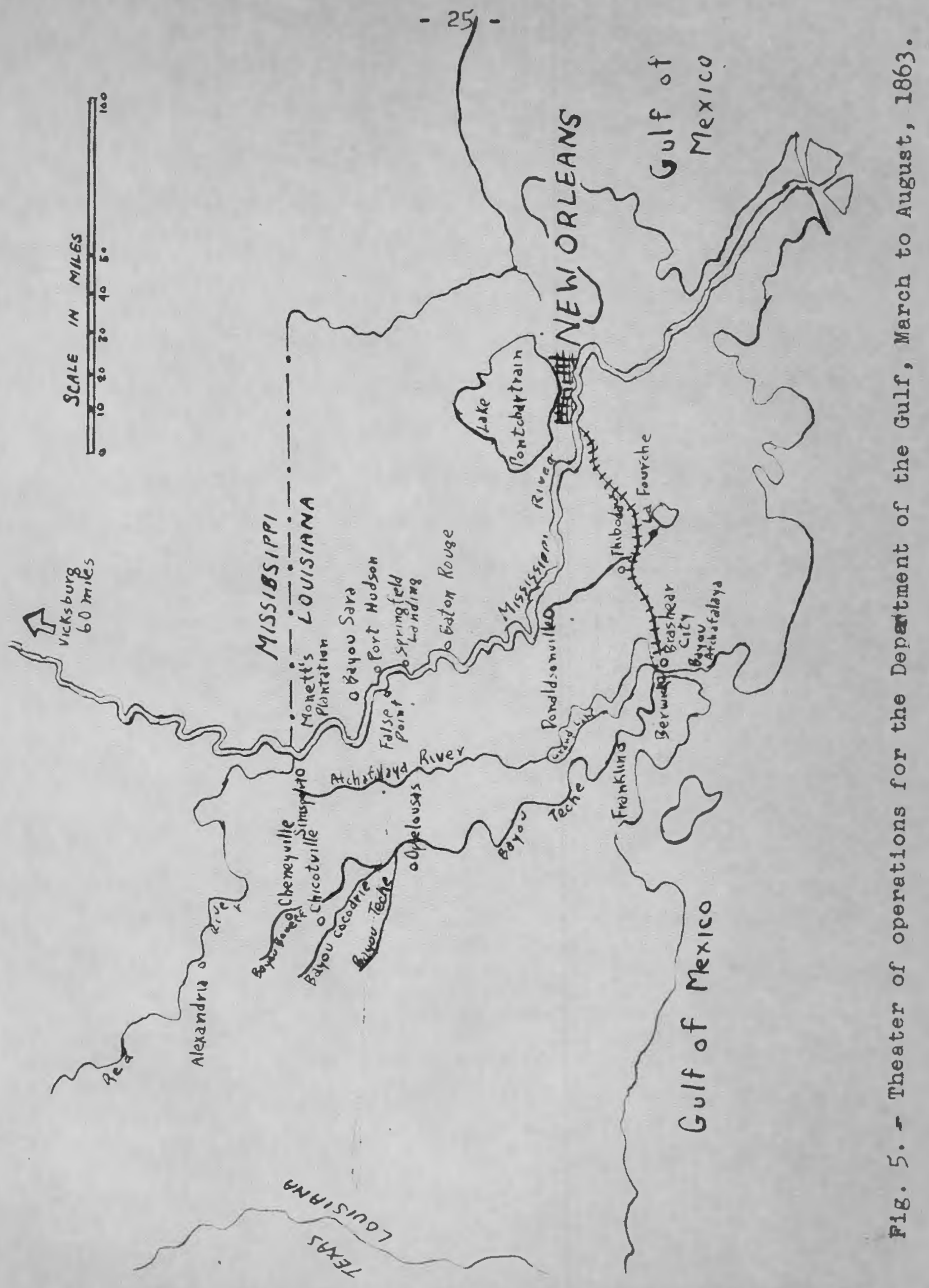




$$
-26-
$$

sent back to ascertain, if posalble, the movements of the enemy. 1 This time he traveled as far as fifty miles in front of the advancing troops, and found nothing. The road from where they were to simsport was reported good, and the party had pushed all the way through chicotville. Onlf a small picket of the enemy was enoountered, and Colonel Corl1s captured that. He reoomended strongly that the Department push on to Alexandria.2 To make sure there was absolutely no cavalry in the area, Major Robinson was ordered out with the romalning oavalry to disporso anything ho found.

The Slege of Port Hudson

It was at this point that General Banks doolded to abandon his original plan to reinforce ceneral Grant to the north, and Instoad, olected to move suddenly back to Sinsport (seo Flgure 5, pago 25), oross the M1salssipp1, and try to take Port Hudson from tho other side. General Augur's division had gotten into position and the rost of Banks force was to rolnforoe him. On May 18 the second Rhode IsIand Cevalry moved to Honett's Plantation, and started on the Bayou Sara Road. By May 25, they had roached Bayou Sara and moved on Port Hudson.3 By May 26 General Benks was able to mess 14,000 men against the confederate fort. The next day with him.

It is not clear whether he had any of his own compenies 20R 1-15, 305 .

3Dyer, Compendium, 3, p. 1627. 


$$
-27-
$$

he attaoked. The infantry, not having taken a complete roconnalssance of the terrain, faltered in an open area under difect fire of Confederate sherpshooters, and the assalt falled. General Eanks settled down to slege operations, During this period (May 28 to July 8) the siege of Port Hudson tools plase. Trenches were bullt by the Federal forces in order to inch closer and eloser. Siege artillery was brought up and placod in position. Moanwhile the cavalry was froo to reconnolter and patrol. The two compenies that were attached to General Emory's division were compted with six companios of the lloth Nev York at Fausse Point, on the western side of the Misisippl River, opposite Port Hudson. Protecting Banks' right flank, they were also to protect the Union Ravy now froely moving up and down the river. At one point a skirmish awarded them eleven Confederate prisoners, among them men of Influence, acjor Vigne, "who is representod as having takon active part in the robellion, drilling, and forcing conscripts into service."I

During the slege, very little action took place in and around Fort Hudson, but elsewhore in General Banks' command, numerous akirmishes took place. Throe of these battles conoerned the Second Rhode Island Cavalry. On June 23, Mafor Anthony'g garrison at Breshear C1ty arrendered. On July 2 colonel Corliss led a charge on a group 
$-28-$

of Confederate ralders. These throe bettles will be treated in detail in chapter III. 


\section{OHERATIONS: JUNE TO AUGUST 1863}

\section{Brashoar C1ty}

8lokness was a major factor in diminlshing effective strength throughout the campaign in Loulsiana. In the first place, the great majority of Federal soldiers in the Dopartment of the Gulf were from the New England states and were not acoustomed to the olimate of the bayou country. Secondly. 1t was late spring and the constant rains had not allowed many men to stay dry. As a result, the disease rate ran high. It ran oonsiderably higher than all other oasualties. During the entire camplgn, the regiment lost seven men due to onemy action, whlle thirty-seven were disabled from disease, fourteen of whon actually died.1

During the righting in western Loulsiana, Major Anthony had been taken slok, but continued in command of bls battalion unt11 yay 19, when the regimental medical diroctor sont him to the hospltal at Brashear City. He had remalned in the saddle most of the time be had been alck, and the modical difeotor felt that the rest wes neossury. 2

lieglater. These flgures were complied by survey of each non in the regimental roster.

I Ibid., p. 160 . 
General Kirby smt th doelded to come beok from western Loulsiana and attempt to rooapture General Banks' base of operations at New Orleans. To accomplish this, he looked to General Rlchard Taylor, the Confederate commander who had fled into Fexas the month before. Taylor had reorganized his forees and recolved replooments until his group consisted of five thousand.1 He left Washington, Loulsiana, on June 10, and moved twentj-eight miles to Morgan's Ferry by one of the few roads that was left pessable from the rains. He crossed the Atohafalaya on June 14 , and rode along the Bayou Fordoche with the intention of reaching the M18sissippl at Hermitage Landing, but a broken bridge turned bim northward round the sweep of False River toward Waterloo.2 (Soe Figure 6, page 31).

At this point he came upon a poderal force at False Polnt, consigting of the lloth New York and relnforced by two compantes of the Second Rhode Island Cavalry, 3 under the command of Colonol C. H. Sage. Taylor Imodiately attacked.4 Sage realsted $\mathbf{w}$ th his pleket force, but as soon as he disoovered the true strength of the confederates, he moved down the levee to the oorner of the lower fleet that was anchored

I Batties and Leaders, p. 595.

2Irwin, p. 237.

It oannot be determined whloh companies.

4Renneth P. W11lians, Linooln Finds a General (5 vols.) Hew York: The Uacmilian Company, 1959), V. 42. 


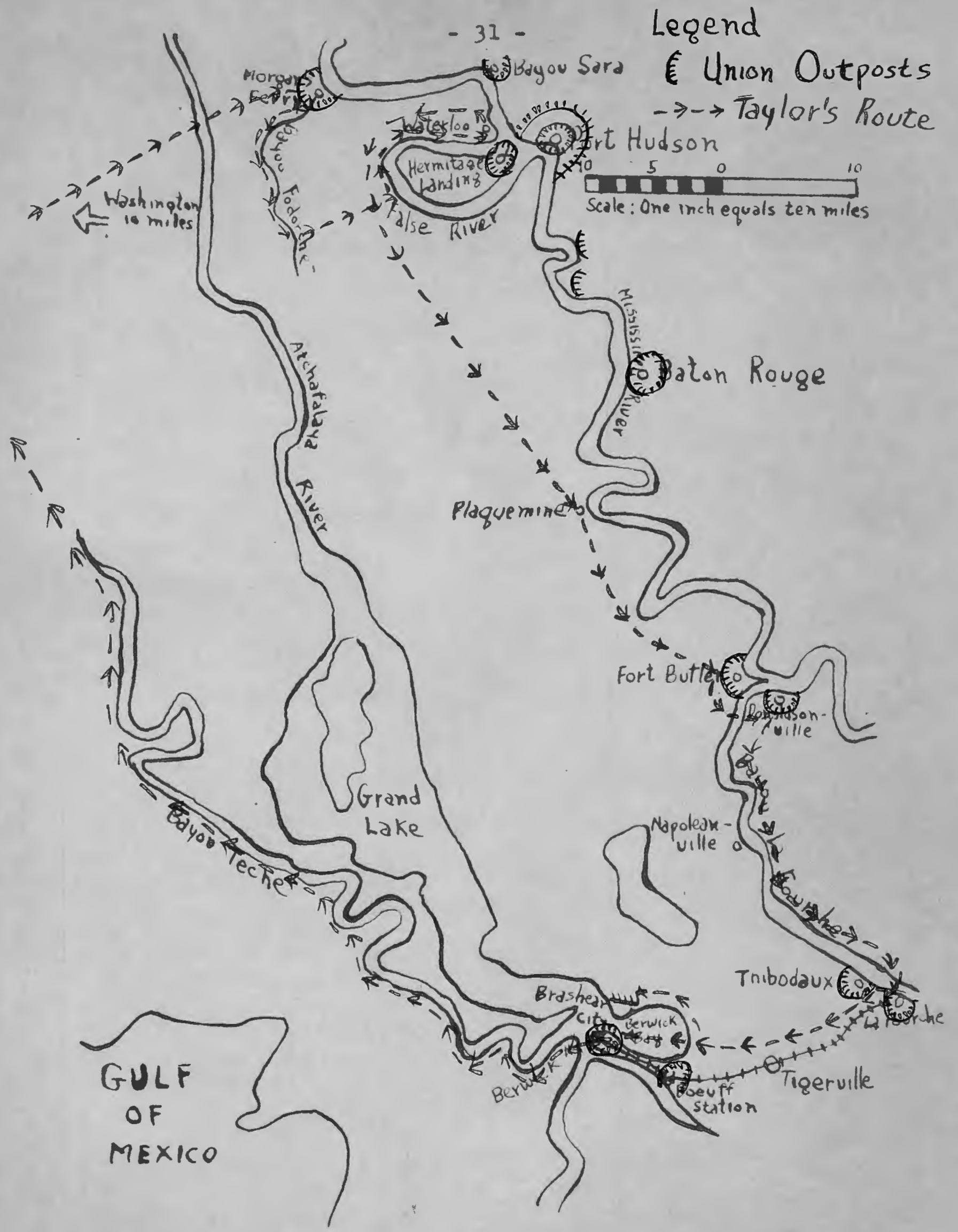

F1g. 6. - Route of General Taylor's Rald, June 10 to June 23,1863 . 
off shore. How under the protection of the gunboats, Sage was safo. Taylor, sonsing the danger of the Foderal gunboats, baoked up and rode of through Plegnemine and then down tomards Donaldsonvillo. Sage's actions protected his foroe, but lost the ohance of giving timely warning of the confederate force in the rederal rear area. 1 Taylor atruck Donalasonv1110, but was beaten off bJ a greatiy outnumbered Jnion garrison. Haktng a folnt at Fort Butler, and under cover of night, he took the out-off and struok the Bayou La Fourche, alx miles below Donaldsonville.

Lieutenant Colonel stickney, comanding the 47 th Massachusetts, recelved word from Department of tho Gulf Roar Headquarters by telegram at 0400 hourg ${ }^{2}$ on June 20 , informing bim that the enery was approeching La Fourche Crossing, and ordering him to send relnforcements to that point. Colonel stlokney, fudgling that Brashear alty was safo for two days at least, left only a small garrison there and moved the marity of his force to La Fourche, intending to return as soon as possible to Brashoar City.3 Genoral Emorg in Hew orleans sent four hundred men to help him. Taylor was beaten off on June 20 and June 21 at La Fourche. A smeller

Irvin, p. 237 .

2The twenty-four hour clock system boglns at midnight. 010018 one $0^{\prime}$ olook in the morning. After twelve olclock noon, the numbers continue, so that 1300 is one olclock in the afternoon, and contimus through 2400, which 1s midnight.

3 OR 1-26-1, p. 193. 
force under a Colonel C. E. Hafor was alspatched to malbodauk to dee if they could get around Stiokney's flank. At Thlbodaux, Hajor captured the entire garrison of one hundred Union convalesoents. 1 Taylor struck again on June 22, but was repulsed.2 Taylor now turned his attention to Braghear Clty.

On the afternoon of June 22, Stiokney recelved word to send two companies back to Brashear city to atrengthen the garrison. At the time stiokney had left on June 20 he had appointed uajor Anthony commander of the garrison. Although there were several others who had more rank than Anthony, he was the only one well enough to as gume command. Stiokney had served with Anthong earlier in the campaign and had confidenoe in his ablifty.3 Further, he relt that raylor'a Texans could not do much damage bocause they were poorly armed, pooriy trained, and had not yet fought any alzable Union force.4

Major Anthony' command conslated of two companies of the 166th Hew York and about fifty troopers from the 47 th Massachusetts, Colonel Stiokney's untt. The others, prinolpally convalesconts, represented at least thirty regiments from General Banks' foreo, Ineluding some from the second

IIrw1n, p. 237.

2w1111ams, v, 42.

3 OR 1-26-1, p. 580 .

4 Ibla. 


\section{$-34-$}

Rhode Island Caralry. 1 Mojor Anthony organtzed them into watohos and strengthoned tine fort against an attak from Berwlok Bay.

On the morning of June 23, Taylor first set up field pleces across the bay opposite Brashear Clty and bogan to fire. Anthony's garrison, aroused in ono hundred per cent alert by the bombardment, started to return the f1re 1 th their own guns, The entire garriton was placod in and around the part of the fort facing the bay and were readied to ropulse the assault that was so cortaln to como. The Union gunboat Follyhook approsohed to within rifle firling distance, but the fire was so hespy that it was beaten off and becked down the bay out of action. 2

Meanwhile, Taylor's infantry, under covor of darkness in the carly morning, orossed Berwlok Bay in make-shift okffe that they had been preparing all the night bofore. They landed on the south shore to the ast of Brashear City between It and Ramas. Under the command of Colonel lunter, they moved into the woods. At about 0630 hours, Hunter gave the order to $f 1 x$ bayonots and forbade them to load their rifles. The confoderates stormed out of the woods, crossed the rallroad, captured the rallroad station and started toward the garrison on the edge of the bay. Taken eompletely by surprise, Anthony's troops gave only

1OR 1-26-1, p. 911.

2Irwin, p. 241 . 
token resiatance and surrendered to an attacking force but half their s1ze.1 The only Federala that esouped were the Provost Marshall and his staff who had been on the gunboat that had been beaten off.' Anthony and more then seven hundred offloers and men were captured by Taylor's confederates.

The Confederacy was over joyed. Sechetary of War Seddon, in roporting to Prosident Davis, termod it a "brilLiant suocess."3 Anthony and his mon and other prisoners osptured at Bayou Boeuf were taken back behind Confederate Ines on June 27. Considerable oorrespondence now occurred between the two s1des, and July 25 over 1,360 unton soldiers were paroled back to Jnion hands. 4 Major Anthony was now out of the illitery pleture, and on August 1, 1863, ho was mustered out of the servioe.5 He returned to ProvI dence.

\section{The Forago prain Inoldent}

Meanwile, the greater part of the flrst Battalion was on the east side of the Missisalppl Miver with General Banka' force besleglng Port Hudson. Colonel Corliss was in

Irwin, p. 241.

2Report, Colonel Taylor to General Smith, June 23, 1863, a quoted in williams, v, 44 .

30R 4-2, p. 991.

4Ib1a., 2-8, p. 60 .

SReglster, p. 164. 


$$
-36-
$$

comand and the battallon had sundry responsibilities, including ploket duty, reconnalsance and soreoning missions. On Jun 20 colonel Corliss' group was part of a langer force sent out to protect a forage trainl between clinton and Jackson, Loulsiana. (See Figure 4, page 23). The force consisted of two hundred and firty men of the 52nd Massachueptts Infantry, one hundred and twenty-two men from the Second Rhode Igland Cavalry, and about two hundred and Ifty men of the 6th and 7 th IIIInols cavalry. 2 Colonel Grierson's Illinols Cavalry had just sompletod a record making raid through the back woods of H1salesipp1 as a diversion to Grant's attack on V1eksburg, far to the noxth. Suddonly, the group was attacked by two rogimente of Arkangas Infantry 3 and hoavy cavalry foroe, supported by two pleces of light artillery. The Phode Islanders were in front of the column when the Confederates opened fire, and they returned the flre. Holding them in cheok, Colonel Corliss sent for his own artillery to vupport the derence. The Rhode Islanders dismounted and took up firlng positions. The artillery must have misunderstood the message, for Colonel Corliss had to send back for thom two times more. In deaperation, seelng the serious stuation that was

Zlipod for the horses.

2noport, Corlise to State Adjuhant cenoral E. C.Mauran, Adjutant General's Bepert for $1863, \mathrm{P} .22$.

3Ibla. The 11th and the 17 th regiments. 
developing, Colonel Corliss turned, galloped beok, and oommandered the rleld pleces that he noeded and started back up to the front of the colven. He reaked the position just in time, for as the Confederates were reaching his posItIon, the fleld pleces flred at thom. Uaing all together tponty rounds of spherieal sase shot, Corlisat I1ttlo group suceeded In wounding seven and klling one of the onomy. Tho assault wevered. Tho Rhode Islanders rushed forward and saptured four confederates. Tro men in company wero takon prisoner, and Lleutenant $\mathrm{f}$. C. Pomroy and Private Prank Brucker were both wounded. Leter, when returning to Port Hudion, the train was again attaked. Thls time the Rhode Islanders were in the rear and $8 \mathrm{al}$ no action. The Confederate onptured about sixty wagons.1

\section{Springfield Landing}

The Second Rhode Island Cavalyy roturned to the main fores under General Banks Before Port Hudson. Confederate Colonol Jonathan L. Logan, comanding a portion of the position noar Port Fudsor, noar CIInton, Loulsiana, decided to make a diversionary rald in Banks' rear to take away some of the pressure against the fort. (See Figure 4, pege 23). He moved out under cover of darkness on July 2 , with a entralry force of about two mondrod. His objective vas Springr1old Landing, an Important oupply base for Banks' 


$$
-38-
$$

bosieging aray. From here, supplles were beling forrlod up the Missiasippl another six miles to be sent overland to 1. treop: 1

Taking the small protective garsison oompletely by aurprise, Logen lmudiately drove in. the ploket of the 162nd New Tork Infantry botit 0830 hours. Before the alam had t1mo to be sounded, Logan's troopers had galloped one hundred jards Into position and broken Into three groups. Group one galloped Into staok of supplies that was protected by Foderal Hegro troops. Upon belng attaoked, the Nogroes flod Into cottonwood grove nearby and watohod the confederates set flre to all they could flnd.2 Group two galloped into the oettonwood grove, scattering and terrifying the Nogroos. Some even ran terrifled into the river and drowned. Tpoup three, consisting of about half the orlginal foree, moved gtralght through the postion towards a 11ttlo hill on the other side. Here they met with more Federal piokets. Capturing some, they now oame race to face with the second Rhode Island Cavalry.

From report that there was a party of enomy oevalry In the area, and rearing for the divialon's mall, General Dwight had sent for Colonel Corl1s and his rogiment early that morning. Corlias was told to met a Gaptein Godrey of the Loulsiana Cavalng, a member of Dught's ataf. He

$10 \mathrm{R} 1-26-1, \mathrm{pp}, 72-74$

2Ib1a. 
would direet hila to the proper plaoe.

Mooting w1th codfrey, who himself had fifteen men, the two gropps started toward the saton Rouge Road, near 8pringtleld landing. Logan had not yet atrukk. It was at111 about 0730 hours. Corl1sa' men had boen in the saddle sinee 0200 that morning. Frerything was quiet, and the party of rebel eavalry prevlously reported was nowhere to be found. Corl1ss and codrrey started back. I It was now 0800 hours.

Suddonily a mostenger galloped up after they had gone a for miles, and reported that Logan had attadked the supply base. In addtion, they came upon two offloors in a comand buggy. The sentor offloer, General Augrar, turned to Corliss and told hil of the cerfousness of the aftuetion, ordering him to return to springr10ld Landing and save the applies. Augur drove of repldly in the direction of Port Hudson to report to General Benks.2 corlis: immodiately sont an offleer to move down the road as rapldzy as poselble and gein any Information he could. At the same tine, he turned the colum around and started beok. After they had gone a mile thoy were startled at rocelving a "wcattering bot" from the confederates. 3 colonel corl1ss had run into group three of Logan's cavalry.

1on 1-26-1, pp. 139-40.

Irid:

3 IbIa. 
The Rhode IsIanders answered with volley of the1r own ss soon as they had time to dismount, and, forming into - coluan of fourg, advanoed. Group thre foll back on Logan's main force. Corllss followed and charged egaln, but was repulsed. The full, welght of Logan's force now counter-charged. Groatly outmumbered, Corl1ss withdrew. Mid-morning in July in Loulatana, the sun bot down on the road. Dust kloked up so thiokly that it was impossible to tell friend from foe.

Company $D$, leading the retreat, now camo upon confed-rato Infentry to their front. Captain Boach gallopod back to Inform Colonel Corliss of the new development. Corlisa ordered a charge bout threo bundred jards from the road, toward the advancing infantry. The infentry foll baok in the direction of Logan's cavalry, and nothing more was soen of them, 1

How reinforeed by Colonel Blanchard's 162 nd Now York, the Federala forced the Confederates back. Logan, however, held on unt1l all the supplies had beon burned. Destrojing one hundred wagons, Logen k11led or wounded one hundred and forty union troops, and eaptured two lioutenants and oleven enlisted mon from the Second Rhode Island Cavalry.2 Lieutenants Whitney and Fenner were never paroled with the rest of the men captured. Both were taken the following Doomber

IOR 1-26-1, 0. 140.

2 Ibid. 
to Libby Prison in Charleston harbor. Lieutenant Fonner made an herolo escapo in Warch, 1865, st Northeast Forry, North Carolina, and was honorably discharged Harch 12, 1865.1 Colonel Logan's actions at Springfield Landing were comended by the Confoderate General Johnston, comanding at Jackson, Loulalana, for "exhlbiting $\nabla 1$ gor, enterprise and courage." 2

\section{The Surrender of Port Budson}

The Confederate defenders of Port Hudson, weakened and disheartened by V1oksburg's surrender, resisted with all thelr reserve. Banks, reajy to mount another assalt, demanded their surrender. On July 5, 1863, the day after Grant marched Into Vicksburg, Port Eudson struck its colors. The Second Rhode Island Caralry was atill divided into the varlous companies attached to the sub units of the Department of the Gulf. But now that the flghting had stopped, it consolidated at Baton Rouge. Companles $\mathrm{E}$ and G oame in frow ploket duty at Fausse Point, Company arrived from Hew Drloans, and Company B oame from ceneral Banks ' hoadquarters. Deolding to concentrato his cavalry at various places, Banks sent the Seoond Rhode Island Cavalry to Thibodaux.3 They were assigned to the Oomander of Defontes of New Orleans.

\section{IRegistor, p. 178.}

2OR $1-52-2$, p. 505 .

3 spectal Orders No. 200, Headquarters, Depertinent of the Gulf, August 15,1863 , as quoted in OR 1-26-1, p. 685 . 
CHAFTRR IV

DUTINY AT CAMP HUBBARD

The Reduetion

Volunteer units in the civil war, unlike those of the Hegular Arng, reoolved roplacemente from the home atate. Sine the drive on pert Hudson did not recelve the publlolty that miltawy operations in tho Best reeelved, it did not prove to be popular. As a result, there were fow volunteers fron the recrulting atations in Providenee to $\mathrm{f} 111$ the ranks of the second Rhode Irland Gavalry Reglment. Furthermere, dinease, battie casulties, and losacs by capture contimed to roduce the rank and Filo. The task of reauplying the regiment with replcoement troop began to assume huge proportions in view of the large desertion rate. 1 The Seoond thode Islend Cavalry, I1ke all other eavalry unts in the C1V1I Far, loet more men while on outpoet duty than in pltahed battles.2

This wher and tear now made the number of mon present for duty sink well below the strength permitted for this type of unit. Gonopal Banke dooreed that they could not be

IDesertione w111 be disousaod in detall In Chapter $v$. 2pyer, Report for 1865 . II, 161. 


$$
-43 \text {. }
$$

allowed to go below one-half the minfuum trength of the original structare of organization. This unit was down to throe hundred and sixty-five men. On July 11 General Banks declded to reduce the two battalions to one. Thli battalion would consist of four companies, 1 and would not noed a regimental headquarters. ${ }^{2}$ The order vas sent out, and colonel Corlis, now without a command, togother with four other offloors, resigned his comingsion and started home to Thode Island. Elght offlcers wore rotalned.3 companies $A$ and were consolldated Into new Company A. Companiee B and D bocame Company B, Compantes E and $O$ beoane Company $c$, and Compantes $\mathrm{F}$ and $\mathrm{H}$ became Company $\mathbf{D} .4$ the ight orficers retained wero Captain MoCall and Lleutenant Whitnoy for Company A, Captain Beach and Lieutenant Turnor for Compeny $B$, Captain Hazdy and Lleutenant lianning for Company $C$, and Captain F1tta and Lleutenant Jackson for Company D. 5

\section{IA Repert for 1863. p. 4.}

Zphe Congresalonal Aet of Maroh 3,1863 states that, "whenever a roginent or Voluntoers of the same arm of the samo state is redueed to one-half of the maximun number procortbed by lex, the President may direct the ooneolidation of the companies of such regiment, provided, that no sueh company formed exceod the maximum made by law. When such consolidation is made, the roglmontal offleers shall be reduced in proportion to the reduction in the number of companies." General Banks' order of July II complied with this Ian.

3Reg1ater, pp. 431-32.

44 Q Report for 1863, p. 9. Extracted fron spocial order 107 paragrogh 14 , Headquarters, Department of tho dulf, July 11, 1863 .

5Io1d., Special order 168, paragraph 2, July 12, 1863. 


$$
-44-
$$

Reduction in ranks grow worge, and on August 24 a more important and far reaching deolsion was reached. Special Orders No. 209, Paragraph VIII, Hoadquartera, Department of the Gulf, New Orleans, deted Auguat 24,1863, read:

The enlisted men of the second Rhode Island Caralry are tranaforred to the P1rst Loulsiana Gavalry. The offlcers are hereby mustered out of the serviee. Such of them as desire to remaln in the service may, upon proving tnemselves fitted for and deserving of commiatons in the First Loulsiena Cavalry before a board appointed by its reglmental commander, be appolnted to flil vacanoles. Lioutenant Colonel Robinson, First Louisiana Cavalry, is charged with the exocution of this order. By order of Major General Barks , 1

The Muting

Colonel Haral Robinson, commanding offloer of the Firat Loulsiana Cavalry of Volunteers, took immediate action. From an ajacent birouge area, he sent out his quartermaster to Camp Hubbard ${ }^{2}$ in order to oount and secure the gorernment property. He was eapeclally interested in the horses, as the remount problem was acute in the Department of the Gulf. Ho approached the offloers in Major Anthony's hoadquarters, imploring them for oooperation in the coming changeover. He recelved negative answer to all his requests.

They the Rhode Island offloers informed me none wishod to remaln; none wished to apply for comalsalons in tho

IOR 1-26-1, p. 269.

2Bivounc of the Sooond Fhode Island Cavalry.

3The problem of obtaining replacoment horses. Seo Chapter II. discussion of shortago of cavalry units. 
Frst Loulsiana Cavelry. They did not hesitate in telling me that in tholr opinion I ahould never be able to do anything with their men. They further sald to me that, as they understood 2 the orders 7 they themselves were already discharged from the service.1

By Auguet 29 desertions had inoreased over the prevlous day in the Rhode Island unt, and Colonel Roblnson had not accomplished the mission as stated in his orders. This time he sent his Adjutant, Lieutenant Hall, over to the Bhode Island camp in order to read the order to the men. He did so at 1600 hours. "Instantaneously, and as if by accord, a tumultuous and general, 'Nol Nol was uttered from one end of the Iine to the other."2 "After having taken their names, they were dismissed in order to get their clothing, and report back lmediately, which they falled to do."3 "The men sald they would not serve in the First Loulsiana Cavalry under Colonel Roblnson; that they would endure any punishment imposed upon them, but would not serve." 4

The next morning, Colonel Robinson went over to Camp Hubbard in order to investigate tho matter. All the wen were assembled in amall groups, dicussing the situation.

I Colonel Robinson rode up to them, and quietiy ordered them to take up their pecks and join their respeotive companies. Not $a$ man offered to obey the ordar. Two

I Testimony of Colonel Robinson at Court of Inquiry, OR $1-26-1$, p. 262 .

\section{Ib1d.}

3restimony of Captain Franols M, Iros, First Loulsiana Cavalry, at the court of Inquiry, Ibld., p. 264 .

4 Ib1d.. p. 265 . 


$$
-46=
$$

of them aroge, and used the following language, or words

to this effect: "Colonel, wo have made up our minds that, 2. To onlisted in the Second Fhode Island Cavalry, wo will, by God, serve in no other. We vill not go. Do as you 11ke, but by God, wo won't serve." A murmur of assont ran through the crowd, and not a man moved.1

Roblnson faced a diffieult situation. Sore of the Rhode Island men had already deserted that morning. Their aetions were Indiegtive that atern measures would have to be taken in order to re-establish disoipline. Throe of the oorpantea of his own Loulsiana unit ware reorults, and soinething like this, If successful, might prove disstrous to their disolpline if he allowed the phode Islanders to continue unohecked.

I knew that no guard could hold these Rhode Islanders in oamp. Imprisonment they did not pear. It was roported to $[$ ource not found7 thet they courted being sent to some place of confinement in body, and I was certain that nothing but fear would prevent the from turning into a band of marauders, which would oompletely demoralize the Flrst Loulslana Cavalry, oause the orders of the Department to fall to the ground, and make 11 itary discipline and law a farce. 2

\section{Robinson's Actions}

Robinson acted deliberately and decisively. He sent word back to his own camp to Captain Ivea to eall up the regiment and march them, under arms, to Camp Hubbard, stating that the Rhode Islanders were in mutiny"3 He then went back to spoak to the men again.

I [Captain Ires] hoard three or four of them (Fhode IsIanderg 7 telking with their assoolates, but could not

IColonel Robinson's Testimony, Ibld., p. 263. 2Ib1d.

3 captain Ives' pestimong, Ibld., p. 265. 
hear whet they seid, but should fudge from their actions that they were urging them to mutiny. Colonel Robinson called one of the men up to him and sald, "You are the spokeman for these men tists morning, and are urging thom to mutiny. Do you refuse ory order?" ythe man replied, "Not more than the rest do."I

When the Louldang troops arrived, one company tas mounted, and three were on foot. The mounted oompany was ordered to enotrele the camp, and the three on foot were told to form a line facing the Rhode Islanders. Colonel Robinson, with an interpreter accompanying him, 2 spoke to the men in Engl1sh, Spaniah, and French, ordering them to join their companies,3 The interpreter then repeated the comand in Gerwan.

Not a man of the mutineers stirred. I then told them omphationily that if they did not riso up and for lino, I should order them to be fired on. 4

The three Loulsiane companies were facing the Rhode Islanders. Two were ordered away from the one in the center to form on both of its flanks, forming three sides of a square. The compang in the conter was then placod at the disposal of the Adjutent. Fhilo st111 in the saddle, Colonel

lcaptain Ires' Toatimony, Ib1d., p. 266.

2 A further study indicates that a groat many of the mon reorulted in the second Rhode Island Cavalry's Second Battallon were of forelgn birth, from countries where a language other than English was tine native tongue, such as the German Company, desoribed earlier in thls work. Heg1ster, pp. 164-220.

3The Rhode Islanders had not kept any unit integrity, and had been ordered to integrate into varlous sompanies of the First Loulsiana Cavalry.

4001 nel Roblnson's Testimony, OR 1-26-1, p. 263. 
Roblnson wrote out an order for Lioutenant Hall. It was an order to prooed as Provost Marshell, executing the two ringleaders. One of these men bad inolted the rlot of Auguet 30 , and the other had been a ringleader on August 29. The order read:

First Lieutenant Ha11, Adfutant of the First Loulsiena Cavalry, is hereby appointed Provost Marshall of the Day, and is charged, as auch, with the execution of Private Rlchard Wurphy, Boston, allas Rlohard smith, and of Private Froderlok Freeman, allas H1llam Davis,

The Exeoution

By now, all of the Rhode Ialanders except the two mon who were detalned by Colonel Roblinson's order, had jolned the Louldiana compang to which they had jugt been newly assigned. Company $F$, the Loulsiane oompany that was in the center of the formation, was divided into two platoons. These brought up on line with each other, one prisoner bolng placod in front of oach platoon, ten paces forward. Lioutenant HaIl, the Adjutant, went up to each man and offored hire tille to pray. After blindfolding thom, he $81 \mathrm{gnalad}$ to Lieutenant Jules A. Maslcot, commanding Company F, to fire.2 waoh platoon fired sucoessively, and the men fell to the

lColonel Robinson's Testimony, Ibid. Their real names were Rlohard Salth and 111 an Davis. Apparently the other names, Hurphy and Freman, were the nanes under whloh they had enlisted. "Report for 1863," Register, pp. 432, 454, and 456 .

2Testimony of Lieutenant Masloot, on 1-26-1, p. 267. 


$$
-49-
$$

ground. Smith was only shot through the legs, I Lieutenant Hall and the Orderly Sergeant of Comrany $F$ admintstered the coup de grace with their pistols.2 The muting was over. It had boen put down within a half hour. Colonel Roblnson, shaken with the serlousness of the sltuation, and taking advantage of the astonishment of the Fhode Islanders, turned to the group and said:

Soldiers, and you especialiy of the second Fhode Island Cavalry. . behold here the terriblo consequences of robelilon and insubordination! It is very painful for anyone to be compolled to recort to the ge last axtromities, but be as sured that every attempt at insubordination will be met in the same way. You are now in good regliment under good offloers, who will take care of you, but tho in return 111 demand atriot obedience to orders. 3

Horror stricken with what they had fust witnessed, the men moved into the Loulstana oamp in a very meok manner. Colonel Roblnson started his report to General Augur.

Letter from an anonymous soldier to the Providenoe Daily wening Pros8, Soptember 22, 1863, p.2, 0.2.

2Lieutenent Hall' : Testimony, OR 1-26-1, p. 250.

3Descripticn of the execution, Providence Dally Evening Press, September 22, 1863, p.2, 0.2. 


\section{CHAPTER V}

\section{DISCIPLIME AND MORALE}

Problems at the Beglnning of the War

When the results of the Battle of Bull Run proved to be Indecisive, both the North and the South fell back to their respotive sides to start bullding their milltary forces. To the North, the job of reorulting an army that would be surficient both in numbers and in strongth to put down the Rebellion, proved to be a tremendous task. Large groups of men who had never seen anfform were now thrown together in makeshift carap all around tho capital ofty, building up temporary barricades to protest the seat of the Union government. Consequently, the area around washington was deluged with various unferms, weapons, and dialoota. With no semblane of organization, sanitation, or discipline, unruly soldiers were overywhere.

Many soldiers had deserted, and the streets of Washington were crowded wth straggling of 1 cers and mon, absent from their atations ithout authority, whose behavior indicated the general want of disolpline and organization. 1

General George Mcclellan was given the task of reorganlalng and trainting the Jaion foros. Goneral Minfleld soott

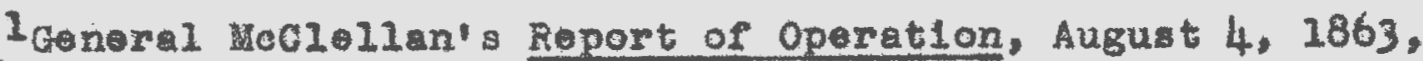
on $1-5$, p. 21 . 
had already made the decision to keep all Regular Army units together. Long before, the Idea of putting the regulars Into volunteer units as cadre for the new reorults had been advanood. Thls was vetoed forfear of having to reoull them from the frontier where they constantiy faced the Indians. So, for the remeinder of the war, units would elther be regular, volunteer, or state militia.

Such a decision created many problems within the volunteer ranks. Competent leaders were at premium, and for the lack of a better plan, men were permitted to elect their company offlcers. They, in turn, voted for the reginental offleers. Persons of influence or mons able to raise groups of men were given commlssiona of colonel by rote-consalous state governor with little on no regard for their experience or formal training. "Polltioal general" paraded around wainglington's most exclusive extablishuent with no ldes of what the unfforin they were wearing represented.

Ilkewise, the men were just as lgnorant. Feorulted initially in 1861 for very short periods of tine, these men had no sense of bolonging to their outflts. Not kept abreast of what the current regulations demanded of the soldier, these men became a disorganlzed mob. There was only the slightest 1dea of why they were in Virginia. At night they left the oamp and roamed the countryside, sometimes, terrorizing the local inhabltants.

It was only a matter of time before this lack of 
dicolpline came to the attention of perwons in high plaees. In 1861 there were two cages of open revolt in the unt stationed axound Fashington. Had thoy not been prompty ouppreseed by the Vigorous Hodlelian, the splrit would no doubt have apread throughout the ontire comand. The prinetpal disturbance oceurred in the Fet Yosk 79 th Volunteera. The men Were "sootoh Highlanders," In battlo thoy had proved to be good flghter: bat they woro "Intreotable in dispostion." Thelr offloers were totaliy incompetent, and aesurters were Inoreasing overy day, until at one mustor there were one hundred and forty mon wlsing. Finalif ar ordor was rooelved to mareh into Virginla, and the men rebellod. Slrieo most of the offleers were drunk, Colonel Andrew potter was sent with - Iarge group of Regulare who "arew up in front of the matineers and propared to wor them down if the would not submit. 1 The pingloadere were ohalned and the orfleers wore dismissed. In another case a regimont was brought to order by tranaporting $\$$ lxty-three offlcers and men to the Dry Tortugas to labos during the rest of the war.

By exeouting posttive action at the polnt of the troublo, Heclelian was then able to look for the origin. I thinlt the trouble arose wore from peor offloers than

I" Heclellan's Own Stery, New York Tribune, August 17, 1861, as quoted In Fred Albort shannon, The Organization and Administration of the Union Army $1861-1865$ T2 vols. CIovoland: The Arthur H, Clark Company, 1928), I, 99-100. 
from the mon," he was able to say. I Problemo arose from dieputes over the length of service, and In meny cases, Ignorane of milltary law. All of these problem vere -ventuelly solved however, by contlnued and rigorous tralning. comptent offlcers axorolatag good lenderahip soon welded the Arry of the Fotoma inte a formidable m11tary force.

Other Insubordinate aets oame up in the future, but thoy covld bo handied with wature judgement, ones the oxigin was determinod. In January, 1863 , the 96th New Tork demonstrated beoause they hodn't been pald. 2 In Horember a -ompany of raryland Howe Guards refused to leave their stete.3 october, 1863, saw a Alegraeprul open muting at Bloomflezd, Hesour1. The commandlag offloer of the post was placed uader arrest in hio quarters by antineers and a guard plaesd over the telegraph operator and his inatrument. A battery of aptillery was drawn up in Iino in front of the houdquarters. After the inourgents were put down by local troopa, a quadruplo court martial dishonorably diamissed all the offloers frow the military serviee. Again, loaderahip was the key ractor.4 Uajor General Foster lecturod his command thust

1shamen, I, 99-100.

20n 1-18, p. 518 .

3rosd., p. 449 .

40R 1-22-1, pp. 707-21. 


$$
-54 \text { - }
$$

It 1s the duty of the Commending orficer to use every -ffort to promote the comfort of the troops, thelr prompt payment, oto. . . The duty of a Reglmental offloer is to use his efforts to put down any attempt at Insubordination, mildiy if he can, by fores and arme If he must. . . The Commanding General hopes that no offleer or solaler will again so fall his duty. Another of feno will surely meet. Its punishment. I

\section{Muting in the Cavalxy}

There 1 s a point of simflarity with these inoldents and that at Camp Hubbard. Not roolizing the influence that was welded by the reglmental offlcers of the second Rhode Island Cavalry, Major General Banks wortalghtedly released them all from the service berore he consolidated the two rogiments. Leadership, then, was denied the enligted men. A perlod of inactivity and grumbling followed the exodus of the Rhode Iiland offlcers. The burden of enforcement rested solely on the shoulders of strange offlcers from another unit, one that had been constantly in compotition with them for several months. This competition naturally led to indignation and bitterness when the consolidation order was sent down from General Banks' headquarters. As In the case of the Marylanders who didn't want to leave their state, these Rhode Ialanders wanted to romain in a unit associated with their home state. But, unlike the case at Bloomfield, the nuting at Camp Hubbard did not constitute an offensive act, rather one of a laok of response. A "st down muting" is hardiy as gerlous as gne in which armed

$$
\text { IOR } 1-18, \text { p. } 518
$$


Insurgents beslege the comanding offleor's telegraph office.

A last point mot be noted. These men were not $18-$ norant, short term rolunteers struggling with incompetent offlcers at the beginning of the war. On the contrary, they were battle-hardened reterans who had boen through the Port Hudson Campagn almost from the beginning. They had displayed coolnoss under flro and had boen acoustomed to m1litary discipline.

\section{Adnintstrative Disolpline}

Finaliy, one must look at the problem of Individual d1solpline throughout the war in order to draw some conelusions. "B11ly Yank" early in the war had no oonoeption as to why he had to remain with his unlt unless excuged by competent authority. One account remains as example. Conditions. at Caxp Curtin in Pennagloanle more than year orter the beginnting of the war were poor. Sentinels were armed with clubs and soldiers came and went as they pleasod. "We rushed the guards to go bathing in the river, and wo did duty generally when it was convenient." With apparently no shame, the ecount retells how on one ocosion, a soldier was absent for threo days on vialt to nelghboring town, and even after that extended $11 \mathrm{sit}$, his absence was not reported.1

1C. A. Ramsey, "Story of Headquarters Clerk and Sergeant Major," The I48th Pennsylvania Volunteers, p. 336, as quoted In Shannon, 1,179 . It 18 important to note that today thore Is alfference between belng "absent without leave," and "remaining absent with intention to desert." In the Civil War, there was no such distinction made. 


$$
-56-
$$

Th1s laok of adminlstrative disolpline on the part of his offlcers was typloal of a great many units of this timo.

Prior to 1861, Army rogulations authorized a roward of thirty dollers for the epprehension and delivery of a known doserter. But then, as the large influx of men camo into the army in the spring and summer of 1861, and wan such a reward would have brought rich dividends for a oollapsing disclpline in the srmy, this reward was redueod by Congressional action to flve dollars plus the apprehenders expenaes. Later, when this was proved to be poor solution, a saten of Provost Marshalls was establishod in the various Congrosalonal Districts of the loyal states. In addition to enforcing the Enrollment Act, these Provost Harshalls were to detain deserters. Later, an aot by Congross provided that after sixty days, a deserter relinquished his right to Unlted States eltizenship. This inoluded his rights to vote, own property, and to hold public off 100.1

The Problem of High Bounties

Another problem was tho large bounties given to the volunteers. The offer of lerge sums of money to those who would volunteer in a cortain regiment attracted some of the most notorlaus rufrians and rowdies that could bo gathored.

lReport of the Frovost Harshull General, OR 3-5, pp. 67677. ThIs is sEIII true in theory. A soldier is "dropped from the rolls a desorter, "after beling absent without leave for a perlod of sixty days. Cltizenghip, however, is abjoct to question only if tho deserter recelves a Dishonorable Discharge. 
In 1862 the allitia Draft Act put a kind of competition Into the bounty syaten and huge sums of money were offered to the volunteors. States compoted woth oah other in bargaining for new recrults. This system characterized the whole later perlod of the war. Substitutes wore nooded and bounties climbed even hlgher. In New England and New York where the reonary element was noticeable in 1863, the prevalling $100 a l$ and atate bounties totaled three hundred dollarg, mich, added to the Unfted states gorernment bounty, oxactly equallod the maximum for subatitutes. In Rhode Island, some of the towne reported offering as much as thre hundred and Ifty dollara in extra bountlea ovor and bove any other bounties under this draft. The second Fhode Island Gavalry adrextisod in the Providence Dally Post a twenty-flve dollar bounty when sworn in, three hundred doliar when the recrut left the state, and seventy-five dollars when disokarged.1 This is a total of four bundred dollars. In addition, they offered the opportunity to settle in pexas after the war. The General Tressurer of Fhode I land reported that for the year 1862 he had disbursed $\$ 103.525 .00$ in bountios for the Second Rhode Island Cavalry alone. Thi flgure represented disbursements for elpht hundred and elghty-one men.2

$1_{\text {November } 11,1862, \mathrm{p} .3,0.3 .}$

2QM Feport for $1863, p .17$. 


\section{"Bounty Jumpers"}

It wasn't long before someone declded that ho could onlist, colleot therbounty, then desert to enlist somowere 1se. Th1s "bounty jumping" was widespread throughout the Horth, wherever high bountles exlsted. Bounty brokerg aprang up, adrancing funds to bounty fumpers provided they could then colleat thre or four-fold the money. The bounty jumpers sometimes traveled in gangs of five to twonty mon. Half of the gang would put on disguises, go into town, and enlist under flotltious names. After colleating the foe, the other half of the gang would then help the new roorults maik good thelr soape. At the next alty, the other half would do the disguising and the enlisting.

From three to five thousand of then bounty jumpers7 wera estlmated to bo on manhattan Istand alone, regularly organlzed in 11ttlo gangs, reveling in well known hotels: each gang in conrand of a bounty or substitute broker who aveneed the funds and furnished the disgulses. I

On Maroh 11, 1865, Provost in New York City saptured five hundred and ninety suspects in one rald alone, .. the most desperate villains unhung. Host of thom [had enlistod and deserted from three to twenty times osek." 2

The Provost Marshall of Rhode Island, after only a few month in office, was concerned with the problem of bounty jumpers. In his words, the bounty frauds "were so varied, II, 72 .

IHew York Tribune, January 2, 1865, quated in Shannon, 20 if $3-4,1231$. 


$$
\text { - } 59 \text { - }
$$

oxtensive, and complicated, thst it [Fag7 impossible to unraval them. . Organizea boales iz the nelghbortigg cities [had7 pre-arranged for enlistment and desertions, and unt1l their movements were discovered, [had] beat carried on to a considerable extent." In addition, ho brought out the problem of the dishonest recruftins offloer. Evidence pointed out that be vent to great lengtins to obtain voluateers, obtaining "the enlistment of a less desireble elass of perrons."2 After the Federal govornment had been induced to furnish transportation for tho roorults, asen Wore transported to Providence from guch far away places as PhIledelphia, Hew York, and Boston, and persuded to onlist. He otimated that only about ten per cent of thege men ever got to their reginents. The rest deserted. The volunteer generally agread to pay a portion of the bounty, ranging from fifty to one hundred and fifty dollars, back to the recrulter. Sixteon wen who had enlisted in tho second Rhode Island Cavalry gigned blank recolpts over to a reorulting offlcer. The officer was to flll out the blanks dividing the atate bounty of three hundredelolars, thus making the ohock

Istate of Rilode Island, Fieport of the Uaited Stater Prorost Marshall of thode Island, WIIIIam E. Hemiln, made to his Exoellonoy the Governor Sprggue by his request, and by him presented to the General Asserably at Its Januery Session, 1863 TPublic Dooument Appendix Ho. S to the Aets and Resolves of the state Logialature for the Jemary, 1853, Sesslon; Providenoe: Alfred Anthony, 1863), 0. 6. Hereafter referred to as put Fieport for 1863 .

$$
{ }^{2} \text { Ibid., p. } 5 \text {. }
$$




$$
-60-
$$

one hundred and fifty dollara. When the atate bounty was pald, the offlcer wa to nay the soldier in cash ono hundrod and fifty dollars, and tak the tate oheok for three hundred dollars. When the state oheok vas oshed, the recrulting offleer would give the reorult pass, thus msking the opportunity for and with the underatanding he would desert. 1

Recrulting became so frenaled, that the Governor of Rhode Island asked for and grot sposial authority from tho legialature to pay a bounty of ton dollarg to the rocruiters for every reorult they were able to bring 1n. The atate Quartermater General reported that this aystem had "rormed no small share of $[\mathrm{h} 187$ laborg." Eleven recrults were able to bring in one hundred and ten dollars to their recrutters In the Seoond Rhode Island Cavalry, That aame yoar, the Thlrd Rhode Island Cavalry pald ton dollars a nead for flve hundred and lghty-two mon. Totel disbursements of tinla type for the year were $22,975.00 .2$

Dosertion Total.

If, In the gang that was ooptured in Hew York, as mentioned carlier, each man was responstble for several desertions, it is afe to astrus that the number of desertions far exceed the number of men that actually left. Combine this with the fact tinat some of tise men were not fulzy

IIbla., pp. 6-7.

2QH Report for 1863 , pp. 3-4. 
aware of the serlousness of loaving their camp, and it is posible to see why the flgures are so relatively high. In al1, the army reported 266,339 deserters. General Fry reported that not all of these men stayed away with the intent to desert, so ho subtracted twenty-five por cont. This brought down the total to 195,255 . He then aubtracted the number that had boen apprehended and deolared that 117,247 men were still at large. When one combines this with the f1gure of 112,901 men that never antwered the eall of the 1863 Draft, he clted a total of 230,148 deserters that had not been apprehended. 1 By Apr1I 30, 1865, the army was able to o1to a totel of $2,254,063$ soldiers thet had served during the war.2 If one compares the aggregate number of deserters not apprehended, to the figure of the total men serving in the war, a ton per cent desertion rate is indicated. Likewise, when a comparison of the number of men under arms in 1865, $1,000,516,3$ was made with the number of deserters who had loft the astuel unita in the field, the rate was again about ten per oent.

It was estimated by the Rhode Island Provost Marshall that there were elght hundred men absent from their Rhode Island regiments and not yot apprehended at the beginning

IFry to Stanton, september 11, 1865, OR 3-5, p. 109. 20R 3-5. P. 600 .

3 Ib1d. 
of the year 1863.1 In addition, searoh of the Adjutant General's Iist in the Rhode Island Register of Yolunteora shows total of seven hundred and lghty-nine enlisted men during the second Rhode Igland Cavalry's existence. of these, the Register further how that throe bundred and alxty-elght elther deserted or wore last reported as abent wlthout authority. This makes the desertion rate for the Seoond Rhode Island Cavalry a very high forty-six per cent. It 1 considerably higher than ceneral pry's ten per cent. Further, if ono considers this flgure of deserters against the number of men present at any one time, the rate rould be even higher. Llttle wonder that General Banks was concerned with the desertion rate of one of his cavalry unitst

\section{Army Just1ce}

One other possible reason for the high rate was the weakness of the judicial decisions throughout the war. Veak punlshmenta, probably due to the reluotance of lnept offleers at the beginning to judge harshly thelr men who had deserted, oontinued to be glven. Army regulations set forth capital punlshment as maximum sontenoo for those convicted of desertion by a court martial. General Fry considered this faot with the weakness of the apprehension machinery as the chief bottleneck in his work. 
"Undue merey," he sald, "to deserters was in harsh reallty a oruel puniabment to those who remalned true to their 1lag." I In the sumer of 1863, not far from Camp Hubbard. a Department of the Gulf General Court Martial lot several deserters of with fines of thirty-nine dollare each.2 It was the exception rather then the rule when men were executed for the offense, and most men wore let of ${ }^{2}$ ith a slap of the wrist. Shannon says of this:

Beyond such minor punishments were tilose meted out by regular court martlal, wuch sentenees extending to the death penalty. Considering the number of desertions throughout the var in comparison to the very small number who were over executed for the offense, It oan be asily acertainod how littio effeot coptisl punisment had, as it was adrinistered.3

10R $3-5, \mathrm{p} .678$.

2Bell Irvin 1ley, The comion Soldier in the Clv1l war (2 vols.) Vol. I, The Life of BlIIT Yank VoI. II, the Lire of Johnny Reb! New Pork? Groeget and Duniap, 1951), 1, 206.

3Shannon, $I, 227$. 


\section{CHAPTER VI}

\section{REACTIOH}

The Court of Inquiry

A Hiltary Court of Inquity was established by the Department of the Gulf on september 4 to investigate the Stocond Rinode Island Cavalry's muting. Made up of five senior officers, It ineluded colonel, two lleutenant colonels, a major, and eaptain, ${ }^{1}$ all members of Wow York volunteer untts. They met for a perlod of three days, during whioh time they heard evidenoe from Colonel Roblnson, Cpatain Ires, Lieutenant Masloot, and sergeant S1dney E. Irving, Sergeant Major of the First Loulslana Cavalry, but at the time of the mutiny, sergeant, aoting lieutenant, and temporarliy commanding a troop in the Rhode Island unit. All these mon were eyo witnesges to the events of the two days. After deliberating a very short time, the court announoed its findings:

I. The origin of the mutiny in the Second Rhode I land Cavelry was the reading of the order of consolidation with the First Loulsiana Cavalry, on the 29th of August, 1863.

II. The course of said mutiny was the reading of spooiel Orders No. 209, Paragraph VIII, Dopartment of the Gulf, consolidating the Second Rhode Island Cavalry, on the 29 th of August to the time of arrest and exeoutican of the two mon of the second Rhode Island Cavalry on the $30 \mathrm{th}$ day of August, 1863.

IOR 1-26-1, P. 262 . 


$$
-65=
$$

III. The supprassion of the mutiny was in a prodit and efficlent manner in wich the ringloaders were exbouted by order of Lieutepant Colonel Harai Roblnson, First Loulalana Gavalry. 1

The indorsement of these findinge by General Banks backed up tinose of the court and of Colonel Foblnson with only the slighteat reservations:

It is probable that order could have been malntained in the rogiment without the applioation of capital punishment to the two men executed; but the oonduct of the Socond Fhode I land Caralry was suoh that it is Imposalble to ay how much or how soon the mutiny would have been repeated.

Severe mosures we required th them. The commanding Genenal regrete the necessity for the execution, but is unable, with his knowledge of the facts, to say that it was not jyst1fiable in oonsiderations of all the fasts of the case.2

Reaction in Fhode Irland

Reaction at howe in Rhode Island was more positive. Speaking for the State, Governor Smith took an active part in protosting the matter. Upon reseiving the nows of the Consolidation Order of August 24,3 he protested on september 4 to the Adjutant General's offleo in Washington. His flrst objection was the fact that the officers had been discharged from the service. "Even should they bo roappointed, they would lose rank by date of oomission." 4 It was bad enough

$$
\begin{aligned}
& \text { IOn 1-26-1, p. } 268 . \\
& { }^{2} \text { Ib1. . . p. 269. }
\end{aligned}
$$

3 There was no telographic communtoation between Nev orleang and the Horth at that time. The nows was carried by dispatoh stemer, normally taking from seven to ten days.

4Letter from Governor Smith to ar Departinent Secretary Stanton, september 4, 1863, OR 1-26-1, p. 270. It is ovident 
that they lost their comenssions, but more degrading to know that their reappolntment lay in the discretion of the offlcers of the First Loulsiana. Secondly, the enlisted men were forced to be in soma other unft, foreign to the one into whlch they volunteored. This wes unaceeptable. "I do therefore. . request trat the order bo revoked by your department War Department7 and the Second Rhode Island Cavalry be allowed to maintain its name and organization." I The letter of the Governor was sent to General Banks with endorsements by the War Department for his comment and opinion. In answer, the Goneral elted first the poor record the unt bad made while under his comand.

- - but the organlzation wes composed mostly of men beyond control. The depradation and robberles were frightful. One or two of the men on the maxch to Alexandris were shot for of fenses of this character. They gave us still greater trouble by the rroneous reports in in regard to tice movements of the onemy. 2

General Banks goes on to say that not only was the oonduct

also, that the Governor was in possession of a petition signed by tioe men which was written at the tine of the mutiny and sent to Providence by way of Captiln Fitts, who came home to be mustered out. Proridence Dally Evenine Press, September 22, $1863,0.2,0.2$.

$$
\text { LOR } 1-26-1, \text { p. } 270 \text {. }
$$

2Letter, General Banks to the War Department, Dotober 16, 1863, OR 1-26-1, p. 262. Although it oannot be ascertained that there were any executions on the march to Alexandria, the fact that thore were cepradations is borne out in a very violent letter contalned in the Providenos Dally Erentng Press of Septomber 22, p.2, 0.2. The letter is from a soldier, perhops correspondunt of sorts, and cocuses soveral of lcers by nunas of gross misconduct, which indicates a perfeotly good reason for the regluent to heve low moralo and a poor state of disalpline, as General Banks had charged. 
of the unlt poor, but upon talking over possible consolIdation, the offlcers from Rhode Irland Indicated that Governor Smiti would not object. ${ }^{2}$

Upon the resignation of the offlcers with this representation and under the exlgeney of which I have described the remant of the regiment, consisting of only 100 or 200 men, was consolldated with a Wew York Rogiment for the purpose of bringing it into some disolpline and proteoting us against, first, their depradations, and secondif, against the pantos that their reports occasioned. 2

Whon this correapondenoe reached providence, along with the news of the mutiny and the actions of Colonel Robinson, Governor Smith again wrote to Seoretary Stanton. Again he asked that the order be set aside immediately, but this time he also offered a substitute course of action. He proposed that all onlisted men who were in the regiment be sot aside to awalt another Rhode Island regiment. In the Army of the Potomac, there was a Phode Island oavalry regiment, the First, ". - whioh is in need of these very men that are now disgraced by being torn from their own organization, and placed in every way alstasterul to them. 3 Yot those men

IPerhapa General Banks was oonfused between theconsol1dation of July 11 and the disbandment of August 24.

20R 1-26-1, p. 262. Again General Banks 1s oonfused between consolldating into a New York regiment and o Ls:. regiment. The flgure of 100 to 200 men present for duty

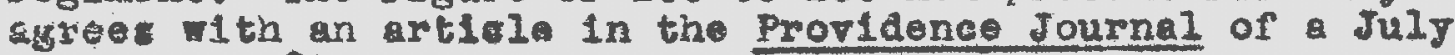
return of 181 mon present.

3It must be remembered that part of tine trouble stemmed from the fact that even though Colonel Roblnson's unit was a loyal one, they still carried the name of the State of loulslana. Under suoh trange elrcumstances, this was too magh for the Rhode Is land Yankees. 
are volunteers. I will ask your own judgement; should thoy be treated so? Do not drafted men even reoelve better treatment.? ? 1

The woek before, the Providence Dally Post had pub-

Ilshed an editorial questioning the validity of the order:

That General Banka, having actual need of Cavalry, - looted the wrong time for consolldating these two regiments. It is no unusual thing for a regiment to be reduced to ono-half its original number. Indoed, Riode Island has not a regiment in the flold today, we think, that oan muster five hundred men. Somo of them cannot muater three hundred. But wo are just now ralsing mon by consoription, and those, of course, may be, and ottght to be, and wo suppose will be used to f1II up these rogiments. No speolal offort was made to 1111 up the second Caralry, and wo suppose that it did not ocour to hlm that it might be filled up with consoripts. This otght to heve ocoured to him, and wo can hardiy doubt that if the consorlpts had boen demanded; they would have been sent. The consolidation was not, therefore, serlously celled for. At least it might have been avolded by a 11ttle orfort, oven if 1 t had beon dotermined that no regiment should be kept in the f1eld after 1 tg numbers foll below fifty por oent of its maximum strongth. But, If wo understand the faots of the case, common justice and the spirit of the law were trampled upon in effocting this consolidation. If wo had half the number of mon nooessary for a full reglment, we were entitled to at least half the number of Captains, Ileutenanta, to., and an equal proportion of ataf offloers. The companies, as the lav provlded, ought to have been consolidated, Thls, if we understand the facts of the case, was not done. Our offlcers were contemptuously mustered out of the service and the men were taken to $\mathrm{f} 111$ the oompanies of the firgt Loulgiana. If this be true, an outrage was perpetrated whioh ceneral Banirs 111 find hard to exouse. 2

Governor Smith next wrote about the execution. It was unbellevable that these men were shot for disobeylng orderg

ILetter, Seoretary Stanton from Governor Smlth, Wovamber 7, 1863, on 1-26-1, p. 271 .

2 Providenoe Daily Post, September 26, 1863, p.2, c.1. 
and inciting a muting. He considered that the men were "simply remonstrating againat an order of consolldation." I He felt that the order was an "outrage to Rhode Island. $n 2$ Peferring finelly to Fhode Islind's excellent record up to then, he brought up the point that undoubtedis it would affect the future of the volunteering program. "What assurance can wo give of $910 e r s$ or rocrults from this state that they 111 bo protected in their righta if they are to be so sumarily dealt with without even show of justice?"3

The Providenoe Dally Post sald of this:

The shooting of two men beoause they manfegtod an unwillingness to be thus transferrod, was oortalnly a most outragoously brutal and unfustiflable affair. Tho regiment had boen notifled that its separate existenco would no longer be recognizsd. The men were, naturally, Indignant, but they did nothing worse than lay down their arms. In this helpless and harmiess condition they were told to fall into ine, as pledge that they would obey the orders of their new offlcers. They did so, with wuch reluctance, and very slowly. The last two wore, at onoe, placod under arrest and shot. Ho trial was allowed thom and there was nothing of the delay usual in the execution of so terrible a sentenoe. The disliked this new arrangement, and expressed this dislike by aoting the part of laggards. This was thelr of fence, and for this they were butchered. 4

\section{The Thlrd Rhode Island Cavalry}

A new 1 dea entered into the ploture when reerulting for the Third Rhode Island Cavalry Regiment started in Prov-

1smith to stanton, on 1-26-1, p. 271.

2 Ib1d.

3 on 1-26-1, p. 271 .

4september 26, 1863, p.2, c.1. 


$$
-70-
$$

1dence in the rall of 1863 . It was discovered that they would also be hoeding to Nor Orleans. Flnal cotion was accomplished on Docember 5 when the War Department wrote to General Banks:

Special orderg No. 209 Tho disbandment order7 has been approved by the General in Chtef. A copy of Banks' report giving reasons for the transfer together with the General in Chi of's indorsement thereon was forwardda to the Governor of Thode Island. Since its reoelpt, the Governor has requested that the enlisted men of the old second Rnode Ialand Cavalry be trensferred to the Third Rhodo Island Cavelry upon it arrival in your Department. For the reasons given by the Governor, you should make this ohange. Wo beve notifled the Governor of this motion. the Third Rhode Island Cavalny w11 depart fos your Department at an early date.I

10R $2-26-1, \mathrm{pp}, 272-73$. 


\section{CHAFTER VII}

\section{OBSERVATIONS}

\section{Was Thore a Iuting?}

The faot that this incident was or wes not muting 18 open to conjecture. Certainly it is true that there was an open violation of normal disolpline. The regiment colleotively was gullty of gross mlsconduct. Since their officors were not present, the men, regentful of losing their unit 1dontity, balked at soldiering in an outrit made up of Southerners, regardieas of their loyalty. To the men, this seemed to juetify the lawlese attitude that took form in the ringleaders, Murphy and Freeman.

Mutiny, a violation of the twenty-800ond Artiole of War, was defined by Colonel inthrop as "consisting in an unlawful opposition or resistance to, or deflance of superior miltary authorlty, with deliberate purpose to subvert or provall over the same."I The key to this offense is the intent. If the men merely hold moetings with view to disobeying the order, but finally obeyed, there would have been no mutiny committed. Winthrop goes on to say that a

IW1111am Winthrop, M111tary Law and Preoodents (2 vols.; Washington: W. H. Morrison, Law Bookseller and Publisher, 1886), I, 821 . 
violent act is not necessary; that the opposition or resistance need not be active or Nolopt. "It thus any consist almpiy in peraletent rofusal or omlasion (with the Intent bove epea(f1ed), to obey orders or do euty." 1 In addition, the realotance had to be of Iawful authority. The inoldent at Camp Hubbard seems to meet all these standards, Pirst, there was Iawul athority. General Banks' order epesif1ed Colonol Robinson by name to effect the transfer of the thode Ielanders to the Louldelana unt. There was definitely an intent to disobey this order. This has been borne out by the testimony of all the persens present. The lden at forth by one Providence editor that the mon "staply leld down thoir exms," 2 is not valld in the light of Winthrop's reasoning. Legally spenkting, throwing down one's arms conotitutos an act of mutiny.

\section{Colonel Robinson's Aotlons}

Even to the most vehementis opposed hode Islander, it must bo clear that a muting did exist at Camp Hobard. Tho b1 queation that anst be settled surrounds the method by Whioh the mutiny was put down. Wext to misbehavior before the eneny, mating is the greatest and most oriminal of tho offenoes known to the mllitury oode.3 Articlos seven and -1ght of the Artioles of War dealt with the punishnent of

Ininthep, I, 621.

2providenee Da11y. Post, September 26, 1863, p.2, e.1. 3w1nthrop, I, 821 . 


\section{$-73-$}

mutineers. Art10lo seven made it dottal offense for a solater to begin, excibe, oause, or jolin in, autiay. Artiolo elght made 1 aldo puntshable by desth to stand by wh110 a muting was taking place.1 In sach of these casos, however, it says that the gcouted w111 be "punlihed as a court martlal hall direot," 2

It is presumed, flrst, that Colonel nobinson obtalned from artiole sevon hls athortty to adudge the douth senterice. Did the oxdar writen by Colonel Robinsentio his adjutant constitute a oourt martials congross gave the authont ty to the Momanding General in the Pleldr to adjuage the death aentenoe. 3 but the order for transfor gere colonel Robinion the authorlty to trander the mon, not to shoot two men in putting down a muting. pooondy, it 1. presuwed thet thonel troblason was ating under perfecty good reasening under artiole eltht, in that it was an offense to stand by when mating gas taking place. Forhaps Colonel Roblnson had thought of otbor taddeath whon rotong and marder took plece and a fow msicet rolloys quollad the mutinoers, Coptainly there mat have been some antagonis between the two units because of thetr olose essociation

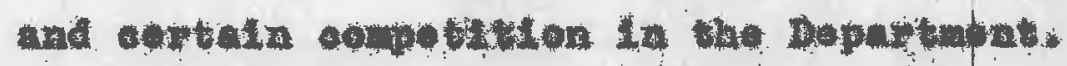

1v. s. Tur Department, Rev1sed U. S. Army Regulations, 1863. Appond1s: Articles of mer Wrashington: Government Finting ofrloe, 1863$), p .486$.

2 Ibla.

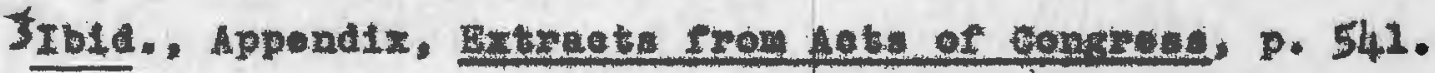


It 18 against the mothod of maphotulea, however, that the oritiolam should be levelod. It my bo sald, firat, that after the First Eouslana Cavalyy troops woro drawn up in front of the fhode Ialanaers, and then were poceably moving aray from the weene, the mating had coand to exist. It was after this that Robinson yanked out smith and Doris. As a matter of fact, these two had been the lagt to leave. These won, then, were presumed to be the ringleadors. In adjudgunt of mitin, Ingleaders are given more sovere sertenoe than other mutineers; ${ }^{2}$ thus Robinson felt that an oxamp 10 muat be shown the rest of the mutineors.

Bat 1t cannot be rorgotten that the law at that ime spectrled the convening of a court martial. Thil suggedts beneflt of counsel, on lapartial court, and witnesses from both sldes of the atory. Whus the actlons of Robinson are considered atronger then were necessery, or then can be just1f1ed. Finthrop says:

While, in extreme cases, an offloer is varranted in omployling the most vigorone means -- in using deady Deapon end taking 11fo - - for the suppression of a mutiny, bo 111 not ordinarily thus be waxranted in a cese of matlay unacoompanfed by violence or where less rohement mothods 111 be ont1rely effectual. It is requidel in every case, in order to justify the legal departure from legal forna, that it be clearly made out that the mutiny was flagrant, and that it alled for strong and Instant peasures to put 1 t down; and that the means used vere not more violent than noedful, and thet it was not safo to walt for the trial and oxecution

Ininthrop, I, 830. "The puntshment belng loft a1soretLonary. the Coart oII naturally and properly adjuge a severer penalty to ringleaders, ete." 


$$
-75-
$$

of the offonders by the ordinary pante of ullitary In sumary, he esserted that:

The mutiny haring been offectulily brought down, no punishment oin be legally inflieted upon the of rendera except through the regular ogurse of justice and the sentenoe of a court wartial. 2

\section{Conelualoas Regarding the Hutiny}

On the part of Banle' headquarters, the report of the Court of Inquiry was a forogono eopeludion. It was convenod In order to disoover, 2) the orlgin of the matiny, 2) the length of the utiny, 3) how the muting was suppressed. No mention was made in the convening of the court as to whother or not a muting cotraliy over exleted. In addition, tho -1theares alled before the court were hal from the Loulalane unit. No atterpt was made to call upon any of the Rhode Islend officers or callited mon. The ofe witnesses who toutified, snoe they were all from the Loulsiand unit, had

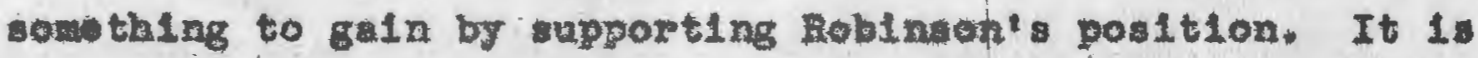
not aurpioing that the court found "th suppreselon in the prompt and erfialent manner." 3

What remaine a question 1 w why nothlas was orer done as the case wont through the varlous rovlews making ita

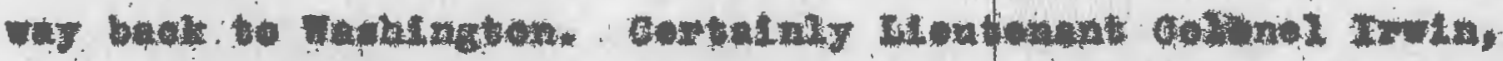

\footnotetext{
ITinthwop, I, 832 .

İuId.. P. 833 .

3or $1-26-1, P .262$.
} 
Banks' Adutant Genorel, mat have had an oplnion. Genoral Banks, exclted as he was over the provlous conduot of his command in Loulaina, had to defend hls concurrence with the court's findings both galnst highor ortioism from Washington, and against open demands made by Governor Sulth. Order was obtalned by Golonel Roblnson by fear more than by good leadership. This 18 a sourge of action not all Amerioan ofricers prefer to take. Roblnson's inpulsive nature indicates his probable course of action under times of undue stress. It is an indication of the way he might have octed in the face of the enemy. General Banks should have taken sorse punftive action against Robinson. The matter was dropped too quickly. That all these mon were oventually transferred to the Third Rhodo IsIand Gavalry upon 2 ts arrival in the Departinent of the Gulf in 1864 is the only bright note in the storg.

Effectivenesa of tine Second Rkode Island Cavalry

It is difflealt to saj bow erfoctive the unft was. In the flrgt plase, there must bo some besls for comparian with other untts of the same type of organizetion. The Dopartment of the Gulf hed only fer ather oavalry unt and none of these were together for any great length of t1me. The various companies were attached to different lafantry regiments to be used for reconnelsgance, soreoning, or plcket duty. As result the reputation of the regiment as a whole deponded on thet of the verious smaller untt 
commenders. Bxoept for the asaeult on Port Eudson 1 tself, the battles as desoribed in this wort are olasifled as skirmithes. There were no conflicts lnvolving tens of thousands of mon as ploksburg, Atlanta, or Oottyaburg. Casualties were very $11 \mathrm{ght}$ and the encounters were 108: frequent than in mang other areas of the war.

some of the battles can be observod, however. At springrleld Landing. Colonel Corl1s seomed to have good control over his unt and they bohaved in good fashlon. Foed with a quick decision, corlis ordered a charge. The fect that the charge falled because they were outumubered does not detract fron the effectiveness of hls cotlone. The Confoderates were not ablo to get past cordlss, and when

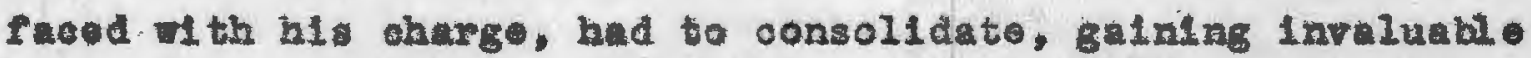
time for the Union troopa. In the Forage Traln Ineldent, Corllas acted with ooblness and oommon sense. The mon under hila were quide to rollow his orders, pad as a rult, the - newy oharge was beten off.

It Is true that, 11 le great many other inthy in the Dopartment of the Gulf, the seoond Rhode Island Oevalyy had some inoldents of poorly disolplined soldiers. Sinoe tho cavalry vas bubltually broken down into small groups, the disolpline was weh more diffloult to malntaln. General Banss had mentioned some trouble with the discipline of 1ndividuals whin his cormand on the marah through western Louldana. There is no mention in the Llst of Volunteers in Dyer's 


$$
-78-
$$

Heport for 1865, howerer, and it must be assumed that this di not Inolude anyone from the Rhode Tillapd unt.

In Ay, Generel Bank roported to Genoral Hallook that ho had had to take "avvere mounwo." 1 Bagadier oenoral mory sald of the Inoldents:

Grave disorders in our rear by the bands of robbers sometines headed by tragglere from the panke, which throatened for a moment to di mupt our communications and oren to disband and disporse into band of robbers and thleves some of our lese disclplined reglmonts, Induced mo to publieh an order Calreoting the 4th Gioconsin to comionoe m111tary operations againgt thon. The inducenents for plunder in this country aro so great that unless hith hunded moasures are taken, many men $\nabla 111$ be lost to the ranks on the day of buttie.2

An embittered ooldier wote home to the Providenoe De11y Erening Prose conoorning the coathet of Captaln Fardy and Booch. Beach had gone difeotly to Banks and promised to stralghten out the disolpline in return for a prometion. But, when the regiment was transforred to Talbodiux, he left at Donaldsonv1110, knowing full woll what was to tranop1ro. Flts, Purner, Jaokson, and Hanning remainod until fow days prior to the mutiny. In fact, hed these offloers stared, the muting might not have taken plece. Captaln Hardy was quostioned for hia behavior in the combat zone, The correspondent oharged that he was always siok when the company was in anger, "no matter how we11 he breakfested in the morning." Freveling through the

Lon 1-15, . . 305.

2Ib1d., 334 . 
combat zone, ho was supposed to have kept four servants in hi. omploy. "He took hone with hin two aptured horses, two now Burnside carbinos, two shotguns, and box containing megnifleont books taken out of home on our maroh to Alexandr1a, What an examplo for the soldiersi"l

The deprodatlone 1 llegediy mado by both offlcers and onlisted men of the roginont evidently continued a bed woputation already established with the poople back bome durlag the activetion period. The men had not ben popular beforo leaving Providenoe. The stroet brawls, the lneldent of the German company, and all the trouble with bounty jumping made the altizens of Providenes think twice bofore ombracing the Seoond Cavalry. Governor Smith's annual message to the state Ioglslature in Jamuary, 1864, did not mention the mating. Only a rew nowepaper editorials covered the alabjoot af Roblnson's astions. After the war, published menolrs of thode Island offlears did not include those who had served in the second Thode Irland Cavalry.

p.2, C.2. 
APFEMDX A

\section{A COMPILED LIST \\ a.}

THE OPFICERS OF THE STEOND RHODE ISLAND CAVALFY

Lleutenant Colonel

Angus tus 1 , Gor11se

Major

Augustus * Corlis:

c. 1. Manchester

Aesigtant Surgeon

H. W. Ing

Jathaniol G. Stanton

Adutant

Eavin A. Hardy

Wolcone Fonnor

Nalter Jackon

Charles 1 Blngham

Quartermaster

W1111 an HoGready, Jr.

Joseph N. Whitnoy

Ceptain

Robert C: Anthong (Ca. A)

George A. Snith (00. B)-

George W. Beach $(\mathrm{Co}, \mathrm{B})$

Henry C. Fitts (Co. B))

Bowin A. Harey (Co.,

Peter Brucker (00, F)

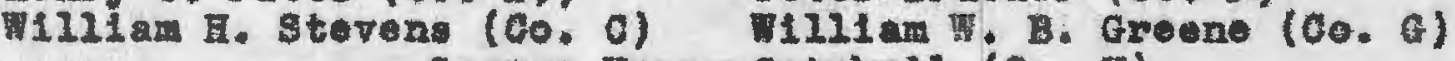
George Henry Getehell (CO. H)

\section{Pret Eloutenant}

Hemey J. Whitaker (co. A) Henry C. Pitte (Co, B) VIIIan J. HeGall (00.6) Millian H. H. Smith (Co, D). Nalter I. Jackeon (CO.D)
John D. Eanning (00. E)

John Bauer $(60,7)$

Charles V. Turner $(00,0)$

Charles E. Blughan (Co. $\mathrm{H}$ )

valter s. Jakson (Co. H)

\section{Second Liorterant}

Edwin C. Pouroy (Co. A) Joseph 7. Whit they (Co, B)

Nalter H, Jackson (Co, C)

Wolcowe Fenner (Co, G)
Frink Iayos (Co. D)

Galeb Brennan $(60$; D)

Herace B. Rogere (00. F)

Chester L. Turner $(00.6)$

agegiater, p. 163. 


\section{A CERONOLOGY OF EVENTS}

\section{2}

August 31 Ordex from Var Department to activate a cavaly's regiment.

Ootober 1 Rhode Island General Orders Wo. 47, actiration of the second Rhode Island caralry.

Horember 15 odder by War Department to make Second Rhode Island Cavalry Into threo battalions.

Deoember 2 Compantes A and B leave Providence for Itow York.

Poenber 12 Company C leaves Providence for Nem York.

December 24 Company D completes filling.

Deceiber 29 Company D Leaves Providence for New York.

$$
1863
$$

Januery 19 Second battallon flllod. A. W. Corlis promoted to Lleutenant colonel.

Januery 20 Company $\mathbb{E}$ Ieaves Providence for Iew York.

January 27 Company Ieaves Providence for Now York.

Jamary 31 Compang G Ieaves Providence for New York.

Fobruary 13 Compenies B, O, D, and $F$ arrive by steamer in New Orleans from How York.

Maroh 5

Al1 companies excopt Company H have arrived from Now York.

March 6-7 Second Rhode Island Cavalry moves from Ner Orleans to Baton Rougo, Loulgiana, by river boat. Two men fall-overboard and drown.

March 10

Companies $\mathrm{B}, \mathrm{C}, \mathrm{D}$, and $\mathrm{E}$ in movoment. Company A left wh departmental trains in Jiow Orleans. Compeny Fith General Augus. 


$$
-82-
$$

March 16 Parmele's attempt with 174 th Ner York and aquedron of Seoond Rhode Island Cavalry to communloate with Admiral Farragut.

March 27 compantes $D$ and $\mathrm{E}$ under Dudieg's brigacle help in oponing up comininications at polnt on the river near the mouth of the Faleo RIver. (Horm1 tage Landing)

Maroh 28 Company I Leaves Providence.

April 1-9 Reglmont woves to Alg1ers, then to Berwick.

April if Regiment is at Franki1n, Loulsiana.

April 22 162nd New York under Colonel Blanchard, and one company of the second Fhode Ielend cavalry marched to Barro's Landing, selzed the position and captured the littlo steamboat, Ellen, tho last of the Teohe rleot.

Apr11 23 Two compante of the second Fhode Island Garalry on an expodition to Bayous Cosodris and Boouff, wh the 4th Wisconsin.

Apr11 29 Colonol oorliss sent forward on the Chlootm v1110 road to ascortain, if poustble, the movements of the enemy.

Apr1 30 Other portions of the regiment with veltedia division.

May 1 Portions of the regimont near Warhington.

Mey 5-18 Expedition from Opeloueas to Alexandrie and Simoport.

May 18-19 Oporations lbout Monett's Plantation and on the Bayou sara roed.

Mnj 22-25 Reglment moves to Bayou sara, then to Port Hudson.

June if Companies $\mathrm{E}$ and $\mathrm{G}$ at mouth be False River, opposite Port ludson, under colonol sage of 110 th Now York.

June 20-23 Lajor Anthony left by Lioutenant Colone 1 stiekney at Breabont C1ty to defond convalesoents. Confederates eapture the fort find all vithin on June 23. 


$$
-83-
$$

Jume 20-21 Colonel Corllss and parts of the regiment are sont out to proteot forage train between $011 \mathrm{~m}$ ton end Jackson, Loulsiana, parts of a largor fore.

July 2

July 9

July 11

July 14

Auguat $\mathbf{2 - 1 5}$

August 15

Auguat 24

Auguet 29-30 Wutiay te Gamp trubbard, Thibodeux.

September

September 5

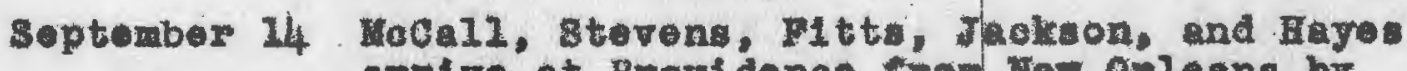
arrive at Providonce from How orleans by cteaver.

Oetobor 16 Goneral Banks writes to Thomas H. Vineent, Ad jutant Gonoral, Washington, endorsing his Il ght to merge tho Second Fhode Island and the First Loulalana Cevalry.

Ootober 23 General Banks endorses findings of the Court. 


\section{BIBLIOGRAPEX}

\section{Publ10 Documents}

Rhode Island, State of. Annuel feport of the Adjutant Genoral of the State of Rhode IsIand for the Yoar 1862. Presented to the Honorable General Assembly of the state of Rhode Irland In Providonoe, December 31at; 1862. Prov1denoe: Alfred Anthon, 1863.

- Annual Report of the Adjutant General of the state or Rhode Island for the Y6ar 1863. Publlo Docurant Appendix No. 4 to the "hots and Resolve for January. 1864 Seselon. Providences Alfred Anthong. 1864.

- Report of the UnIted States Provost Marsha11 of Phode I Gland VIIIIam E. Hamlin Mado to HLs Excellone Governor Sprague by hls Request, and BH HIm Presentod to the General Assembly at its Jamary Sesgion, 1863. Publle Document Appendix No. 6 to the Acts and Resolves." Providenee: Alfred Anthony, 1863.

Report of the Finanoe Committees, upon the Accounts of the Adjutant General, Quartermaster General, and Genorel Treasurer. Pebruar 10, 1863. Pablla Document No. 14 to the Acts and Resolves of the Jamuary, $1863 \mathrm{ses}$ alon of the State Iontulabure. Providenoe: Alfred Anthony. 1863.

Report of the Guartermaster Ceneral, Goorge Lew1s Cooke, Made to tho ceneral Assembly of the state of Fhode Island at its Jamuary Session, 1864. Pablic Document Appendix 10. 3 to the "Acts and Resolves" of the State Logislature, January 1864 Session. Providenoe? Alfred Anthony, 1864 .

- Adjutant General's Report of the State of Rhode IsIand and Providence plantations for the Year 1865. Reglater of hhode Island Volunteers 1861-65. Providenee: Providence Press Company, 1866.

- Annual Report of the Adjutent General of the State of Phode Igland and Providenoe Plantations for the Year 1865. Providence! 2 . L. Freeman and Son, 1895.

$$
-84 .
$$


0. S. Congresstent Reoord. The Gongrestond Act of $\operatorname{March} 3,1863$.

ஏ. \$. Wax Department. Revised D. S. Arury Regulations, 1863. Appendix: Articles of War, and Extraots Irom Aets of Congrese. Washington: Government Printing Orfice, I863.

- Var of the Rebelitioni A Complietion of the offlolal Records of the Inion and Confederate Armies. 128 vols, Washington! Government Printing orf10e, 1880-1901.

\section{Booke}

Dyer, Prederlok H. A Compendium of the Ver of the Rebelilon. 3 vols. Now York: Thomas Yose101', 1959.

Harrington, Prod Harvey. Flghting Polltlclan: Hajor General 1. P. Banks. Philadelphia: University of Ponnsylvania Press, 1948.

Irin, Rlehard B. History of the Nineteenth Army Corps. irei Tork and London: G. P. Putrem's Sons, 1892.

Johnson, Robert Jnderwood, and Brel, Claranoe Glough (odi.). Battles and Leeders of the Clvil War. 4 vols o vor York: The century company, 1888.

Shannon, Fred Albert. The orgenigetion and Administration of the Union Army, 1861-65. 2 vols. Oleveland: Tho Axthur H. Clark Company, 1928.

V12er, BeII Irvin. The Common Soldier in the Givil War. 2 pale. Haw Tork: Crosset and Duntep, 1951.

W1111ans, Kenneth P. Lincoln Finds a General. 5 vols. Hev Yorl: Tho Nacmilian Company, 1959.

Winthrop, M1111am. M111tarr Lav and Precodents. 2 vol.. washington: F. H, Vorrison, LeW Bookseller and Pab11sher, 1886.

\section{Perlodioala}

Provldence Datly Erening Prese, September, 1863.

Providence Delly Journel, August, 1863.

Providence Dai1y Post, September, 1862 -- January, 1863. 